\title{
Kelyphite and Symplectite: Textural and Mineralogical Diversities and Universality, and a New Dynamic View of Their Structural Formation
}

\author{
Masaaki Obata \\ Department of Geology and Mineralogy, Kyoto University, Kyoto \\ Japan
}

\section{Introduction}

Kelyphite is a petrographical textural term referred to a fine-grained, fibrous intergrowth of multiple phases such as pyroxene, spinel and amphibole, typically developed forming a rim (or a corona) surrounding garnet. The name 'kelyphite' was coined by Schrauf (1882) after a Greek word $\kappa \varepsilon \lambda v \varphi \circ \varsigma$, meaning a shell. (Recognition of the shell structure is important in the consideration of the reaction mechanism as discussed below.) Schrauf originally thought that kelyphite represents a homogeneous single phase, but it soon became apparent that it was a fine-grained mineral aggregate. Texturally, it appears to be a breakdown product of garnet, but it is rarely isochemical to the original garnet; this fact implies that the breakdown reaction is a chemically open-system phenomenon involving significant material transfer across the reaction zone ${ }^{1}$ (e.g., Obata, 1994; Godard \& Martin, 2000). On the other hand, symplectite is a more general textural term that also refers to fine-grained, but usually coarser-grained than typical kelyphites, vermicular intergrowth of minerals, which may or may not show radial structure like kelyphites. It may also be a breakdown product of primary phases such as garnet, aluminous pyroxene or some other protophases; or a reaction product between two incompatible phases such as olivine and plagioclase at high pressures (e.g. Kretz, 1994). Kelyphite, therefore, can be said to be a special kind of symplectite, specifically reserved to that after garnet.

Depending on the kinds of primary phases, rock chemical systems and the $P-T$ (pressuretemperature) path that rocks followed, a wide variety of mineralogy and microstructures (texture) of kelyphites and symplectites have emerged, which fascinated many petrologists and drives them for careful observations and to produce analytical works on them. The motivation for the study of such reaction textures is twofold: (1) it potentially provides a wealth of knowledge on the metamorphic history of the host rocks, including the $P-T$ paths that rocks followed, which may further bear significant geotectonic implications and (2) it improves our understanding of the processes and mechanism of metamorphic reactions, which has been another important subject of metamorphic petrology as a part of basic

\footnotetext{
1 A rare example of isochemical breakdown of garnet has recently been found in a Czech garnet peridotite (Obata et al, 2011; Obata et al, in preparation).
} 
natural sciences. Kelyphites and symplectites are ideal objects for studying the mechanism of metamorphic reactions, particularly when both the reactant and product phases are observed to be closely spaced together in a small volume in rocks-typically within a standard thin section size-forming what appears to be a chemically closed system (Mongkoltip \& Ashworth, 1983; Obata, 1994).

This paper focuses on the second aspect. Traditional petrography tends to emphasize and describe rich varieties of reaction textures, which has given rise to a wealth of textural terms but unfortunately forms a barrier for scientists of other fields to appreciate the significance of the interesting phenomena that petrologists observe. I emphasize in this article, by analyzing the observations and considering the physical processes, rather the similarity and universality among what appear to be different varieties and try to present a new dynamic view of the structural formation of kelyphite (and symplectite).

A good historical review of early works on kelyphites is given in Godard \& Martin (2000) and is therefore not repeated here. More recent references include Obata (2007), Naemura et al. (2009), Medaris et al. (2009), Dégi et al. (2010) and Obata \& Ozawa (2011), which are cited in the text. Mineral abbreviations follow Kretz (1983) except Sp for spinel.

\section{General features of kelyphite and symplectite}

\subsection{Mineralogical aspects}

I first classify the kelyphites, for the sake of description, into two types or categories according to their host rock lithologies: (1) one developed in garnet peridotites, in which olivine is an excess phase; and (2) another type that is developed in olivine-free mafic rocks such as eclogites, garnet pyroxenites or garnet granulites. Although both types appear to have been developed replacing garnet (therefore called kelyphite), it was pointed out in early days (e.g., Becke, 1882) that the first type is not simply a breakdown product of garnet but should be regarded to be a reaction product between garnet and olivine; while the second type may be a breakdown products of garnet, which also may or may not be associated with significant material transfer across the kelyphite zones. The typical mineral assemblage of the first type is spinel + orthopyroxene + clinopyroxene. Ca-amphibole is a common accessory phase and may occur locally in place of clinopyroxene. The origin of such mineral assemblage has been interpreted in terms of the reaction:

$$
\mathrm{Grt}+\mathrm{Ol} \rightarrow \mathrm{Opx}+\mathrm{Cpx}+\mathrm{Sp}
$$

or

$$
\begin{aligned}
& 2 \mathrm{CaMg}_{2} \mathrm{Al}_{2} \mathrm{Si}_{3} \mathrm{O}_{12}+(2-2 x) \mathrm{Mg}_{2} \mathrm{SiO}_{4} \rightarrow(2-x) \mathrm{Mg}_{2} \mathrm{Si}_{2} \mathrm{O}_{6} \cdot x \mathrm{MgAl}_{2} \mathrm{SiO}_{6}+ \\
& \text { Grt Ol Opx } \\
& +(2-x) \mathrm{CaMgSi}_{2} \mathrm{O}_{6} \cdot x \mathrm{CaAl}_{2} \mathrm{SiO}_{6}+(2-2 x) \mathrm{MgAl}_{2} \mathrm{O}_{4} \quad(0<x<1) \\
& \mathrm{Cpx} \quad \mathrm{Sp}
\end{aligned}
$$

, where the composition of garnet is fixed to $\mathrm{Py}_{2} \mathrm{Gr}_{1}$ (pyrope 2, grossular 1 in molecular ratio) and $x$ represents the $\mathrm{Al}$ contents of pyroxenes expressed as Tschermak's pyroxene components $\left(\mathrm{MgAl}_{2} \mathrm{SiO}_{6}\right.$ and $\left.\mathrm{CaAl}_{2} \mathrm{SiO}_{6}\right)$ (Kushiro \& Yoder, 1966). For simplicity $x$ is assumed to be the same between the two pyroxenes. It should be noted that mutual solubility between Opx and Cpx is not considered in the above expression. 
The mineral assemblage of the second type is typically Opx + An + Sp with or without Cpx and Ca-amphibole. The origin of this assemblage may be ascribed to another reaction:

$$
\mathrm{Grt} \rightarrow \mathrm{Opx}+\mathrm{Cpx}+\mathrm{An}+\mathrm{Sp}
$$

or

$$
\begin{aligned}
& 2 \mathrm{CaMg}_{2} \mathrm{Al}_{2} \mathrm{Si}_{3} \mathrm{O}_{12} \rightarrow \mathrm{Mg}_{2} \mathrm{Si}_{2} \mathrm{O}_{6} \cdot x \mathrm{MgAl}_{2} \mathrm{SiO}_{6}+\mathrm{CaMgSi}_{2} \mathrm{O}_{6} \cdot x \mathrm{CaAl}_{2} \mathrm{SiO}_{6} \\
& \text { Grt Opx Cpx } \\
& +(1-x) \mathrm{CaAl}_{2} \mathrm{Si}_{2} \mathrm{O}_{8}+(1-x) \mathrm{MgAl}_{2} \mathrm{O}_{4} \quad(0<x<1) \\
& \text { An } \quad \mathrm{Sp}
\end{aligned}
$$

that has the equilibrium position at lower pressures than reaction (1) (Kushiro \& Yoder, 1966). It should be noted that Cpx may not occur if the reactant garnet is sufficiently less calcic than $\mathrm{Py}_{2} \mathrm{Gr}_{1}$ as such:

$$
\mathrm{Grt} \rightarrow \mathrm{Opx}+\mathrm{An}+\mathrm{Sp}
$$

\subsection{Some textural features of kelyphite}

I shall review important textural and structural features of the two types of kelyphites using examples shown in Figs. 1 through 4. Although both types show clear fibrous and radial structure, there are important differences in texture between the two as well as those in mineralogy. The first type of kelyphite is surrounded by a thin rim (ca. 100 microns width) of coarse-grained pyroxenite, consisting mostly of Opx (a few hundreds microns grain size), which is referred to as 'COR' (abbreviation of Coarse Opx Rim)(Obata \& Ozawa, 2011), separating the internal fine-grained fibrous part-the kelyphite, sensu stricto, -from the surrounding olivine matrix (Fig. 1). The COR-Opx typically shows undulose extinctions and low angle tilt boundaries. The COR is not developed where olivine is not present but pyroxenes, implying that olivine is taking a part in the formation of COR. This zonal and concentric structure seems to be universal and has been noted by many authors from early days (see references in Godard \& Martin, 2000). Another common feature, which has not been emphasized in previous literature, is that small, discrete nodular spinels occur sporadically at or around the boundaries between the inner zone (kelyphite) and the COR. We refer such discrete spinels to as the 'nodular spinels' hereafter (Fig. 1, Fig. 3a). The nodular spinel is more chromiferous and seems to be connected to adjacent lesschromiferous, fibrous spinels in the kelyphite. Our prelimimary analysis using electron back-scattered diffraction (EBSD) shows that these nodular spinels and adjacent fibrous spinels share the same crystallographic orientation

Although both types of kelyphites are largely radial in a gross scale around garnet, some features of structural irregularity or internal incoherency occurs, which are best visible in transmitted light in optical microscopy (Fig. 1 and Fig. 2) and they are highlighted in line drawings in Fig. 5. Some kelyphite contain several lines of internal discontinuities, across which direction of lineation (of spinels) changes abruptly. In crossed polarized light extinction angle and interference colors may also changes slightly but abruptly across these discontinuities (Figs. $1 \mathrm{~b}$ and $2 \mathrm{~b}$ ). These lines should represent intersections of planes of discontinuity in three dimensions and the thin section plane. Such curved plane of structural discontinuity present within the kelyphite volume are referred to as the 'unconformity' in 
this paper. It emerges at a certain critical point and may be traced inward to a singular point (a cusp) on a garnet grain boundary as illustrated in Fig. 5. We also note that lineation of the kelyphite, which is defined by spinel lamellae or 'strings', is always normal to the garnet grain boundary at the reaction front. When garnet bounday has a curvature, which is often the case, the spinel fibers change their direction accordingly to maintain locally its orthogonal relationship against the garnet grain boundary (Fig. 5). These planes of discontinuity represent the domain boundaries of kelyphite as described below. In actual formation processes, because kelyphitization starts to occur from the outermost side of the garnet and advances inward, the discontinuous plane emerges at some critical point forming a singular point on the garnet grain boundary at that instance as illustrated in Fig. 12.
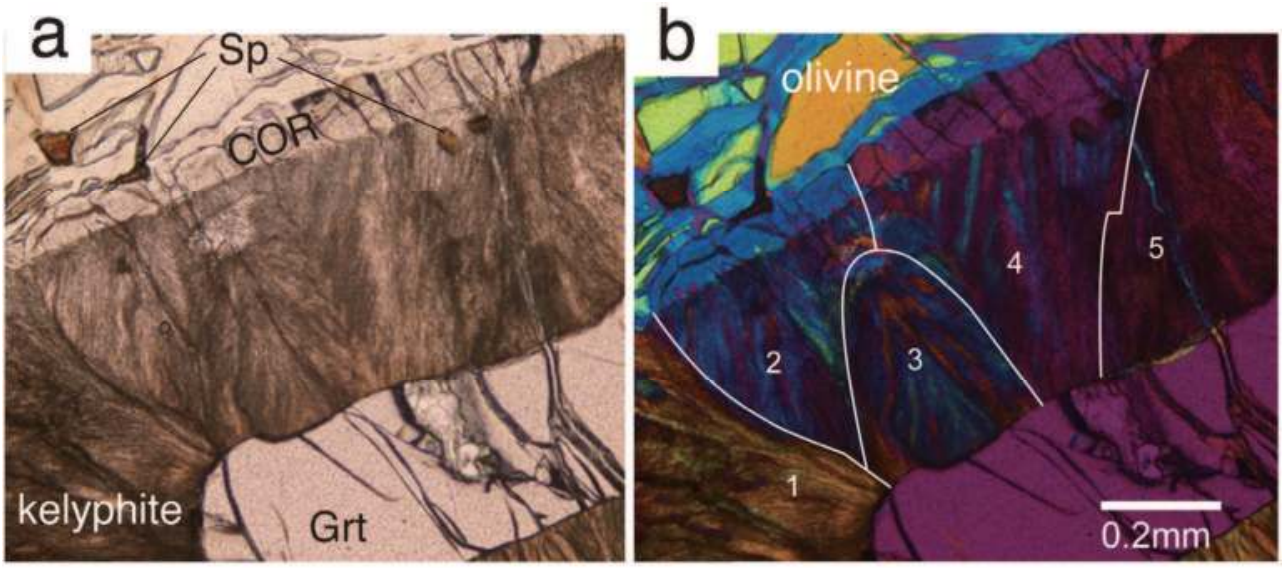

Fig. 1. Photomicrographs of kelyphite Type 1, garnet peridotite, Ugelvik, Norway. (a) Planepolarized light; (b) cross-polarized light with gypsum plate inserted to illuminate the kelyphite domain structure. White lines trace domain boundaries. Domain numbers refer to those in Fig. 8a. Modified from Obata \& Ozawa (2011)
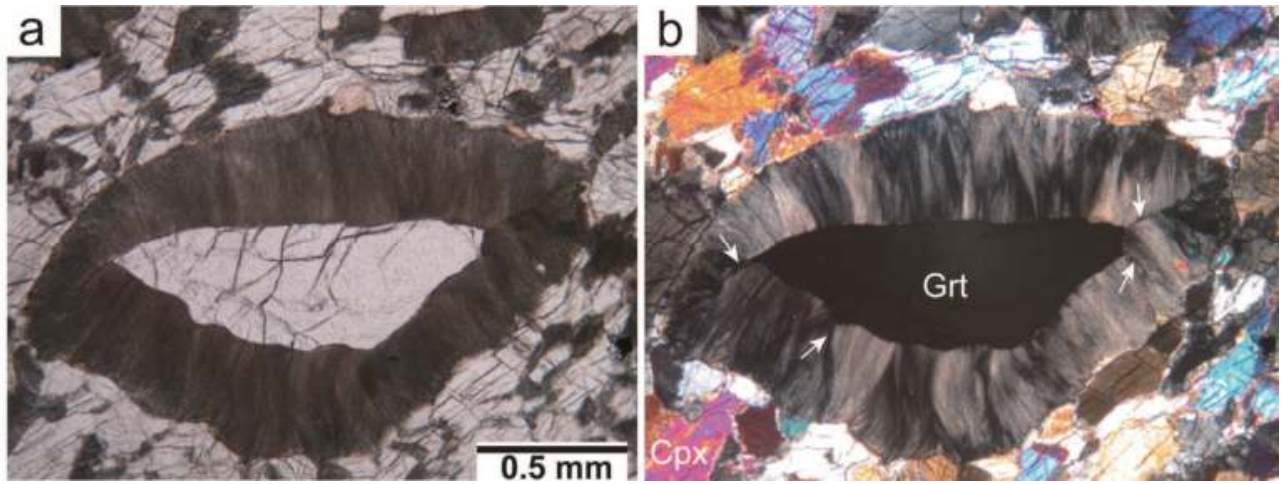

Fig. 2. Photomicrographs of kelyphite Type 2, garnet clinopyroxenite, Ronda, Spain. (a) Plane-polarized light; (b) cross-polarized light. White arrows indicate planes of discontinuity (i.e., unconformities) (cf. Fig. 5b). From Obata (2007) 
Kelyphite and Symplectite: Textural and Mineralogical Diversities and Universality, and a New Dynamic View of Their Structural Formation

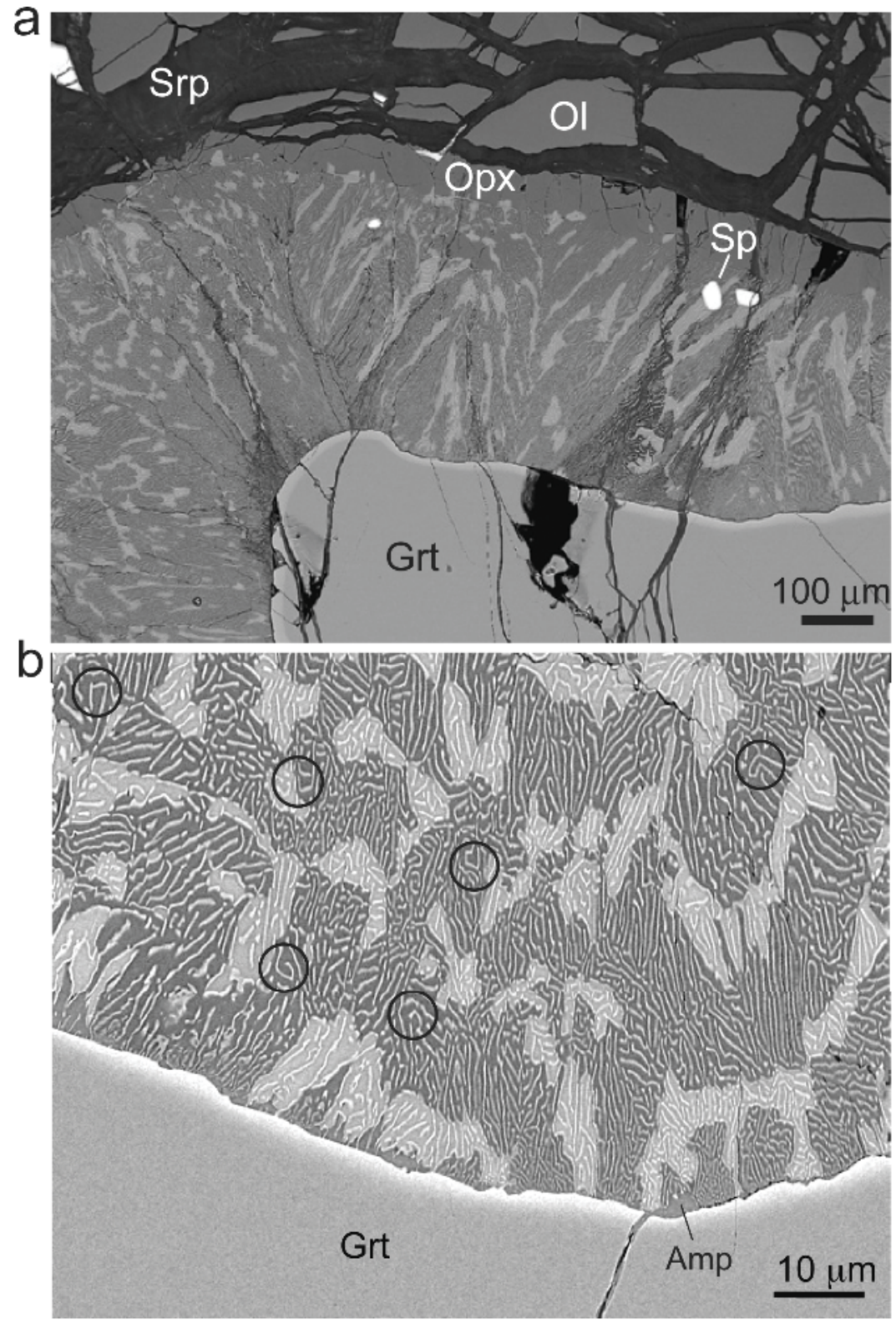

Fig. 3. Back-scatted electron (BSE) images of kelyphite Type 1, showing vermicular intergrowths of Opx, Cpx and spinel. (a) Garnet peridotite, Ugelvik, Norway (refer to Fig. 1); (b) garnet peridotite, Plešovice, Czech Republic (Naemura et al., 2009). Bright 'strings' are spinel; light gray patches, Cpx; dark gray background, Opx. Minor amphibole (Amp) occurs at Grt grain boundaries. Opx forms a single crystal over a large area. Circles mark convoluted spinel lamellae in (b). Srp, serpentine 


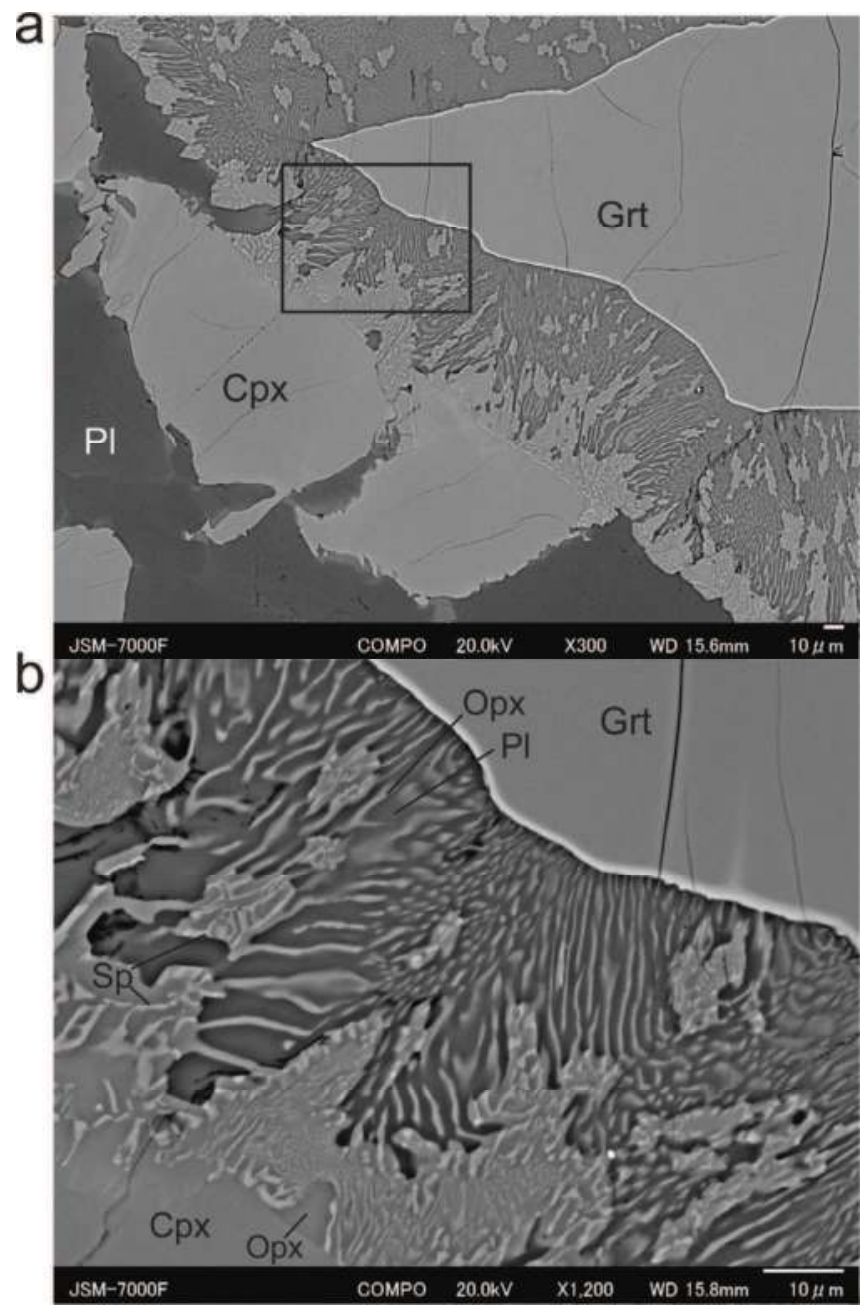

Fig. 4. BSE images of kelyphite Type 2, Ronda (same sample as shown in Fig. 2.) (b) is the enlargement of the framed area in (a). Bright fine 'strings' are spinel; gray lamellae, Opx; dark gray background, Pl. Cpx next to kelyphite is a primary phase

\subsection{The domain structures}

Another important observational feature of kelyphite of the first type, which has not been mentioned till Obata \& Ozawa (2011) emphasized, is that it has a domain structure, in which each domain consists of a large single crystal of Opx that contains several small, irregularlyshaped patches of Cpx (Fig. 3). Both Opx and Cpx contain regularly-spaced numerous thin vermicular lamellae or 'ribbons' of spinel, forming a fine-scale pyroxene-spinel symplectite (Fig. 3b). This Opx domain structure is optically barely recognizable in cross- polarized light (Fig. 1) but the single-crystal nature of the Opx is only confirmed with the aid of EBSD (Fig. 8a; Obata \& Ozawa, 2011). Therefore, it is the spinel and not the pyroxenes that gives rise to 
the fibrous appearance of kelyphites in the optical-microscope transmitted light. Each Opx domain has its internal coherent structure of lineation as defined by the spinel lamellae. These spinel lamellae are remarkably constant in thickness and are regular in the spatial alignment in a restricted area. Looking at more closely, however, the spinel lamellae are not necessarily straight but locally may show curved and sometimes convoluted structures (Fig. $3 b)$. The spinel lamellae tend to 'envelope' or 'outline' the Cpx patches that reside in the Opx. It should be noted that, compared to the lamellar spinel, the Cpx patches are not that elongated and, therefore, do not necessarily contribute to the fibrous appearance of the kelyphite (Fig. 3b). The optical microscopy and the EBSD analysis reveals that the domain Opx in the kelyphite is continuous to the adjacent COR-Opx, keeping the same crystallographic orientation, and thus forming even a larger domain of single crystal of Opx (Fig. 1b; Fig. 8a). We refer this extended domain of single crystal Opx, covering both the fibrous kelyphitic part and the COR, as to the 'cell' and consider it as an important growth unit of the kelyphite as discussed below.
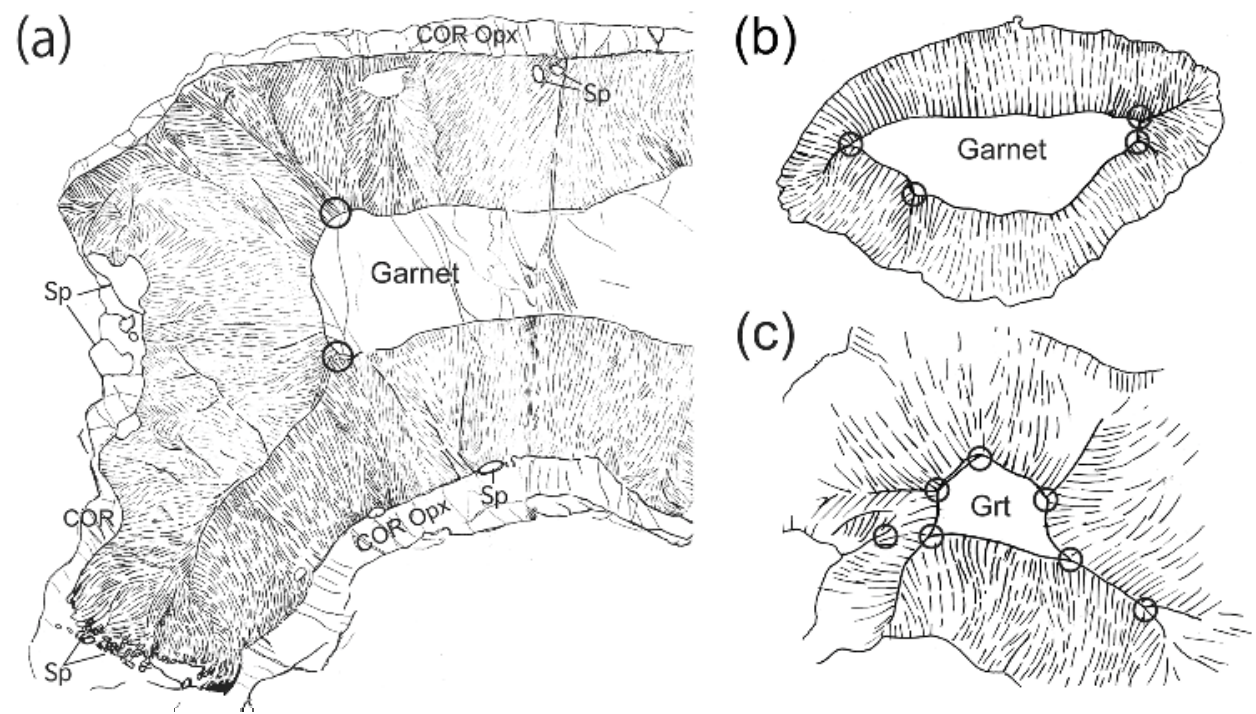

Fig. 5. Line drawings of both types of kelyphite that emphasize internal structures, structural discontinuities (unconformities) and 'cusps' (marked with circles) along garnet grain boundaries. (a) Type 1: Norwegian garnet peridotite (cf. Figs. 1, 3a and 8a); (b) and (c) Type 2: Ronda garnet pyroxenite (cf. Fig. 2; Obata, 2007). Sp is 'nodular spinel'

In the second type of kelyphite the matrix phase of the kelyphite is plagioclase (typically nearly pure anorthite) and not Opx as in the first type. The plagioclase contains many thin densely-spaced lamellae or 'strings' of Opx defining clear lineations resulting the opticallyrecognizable radial and fibrous structure (Fig. 2). Locally these Opx lamellae locally grow to larger patches that contain very fine-scaled vermicular intergrowths of spinel of less than 1 $\mathrm{m}$ thickness (Fig. 4b). These Opx patches tend to get larger and more abundant moving towards the outer margin of the kelyphite. The tendency that spinel occurs only in large Opx patches or thick lamellae and not in the plagioclase matrix has been noted in other localities by Obata (1994; in garnet pyroxenite) and by Dégi et al. (2010; in mafic granulite xenoliths). 
Presence of domain structures in this type of kelyphite is also recognizable optically (Fig. 2b) and is now being confirmed with the aid of EBSD (Obata \& Ozawa, in preparation).

\subsection{Scales of kelyphite and symplectite}

Crystal grain size of or spatial scale within the kelyphites is quite variable among different samples from different tectonic settings and of probable different $P-T$ histories. For Type 1 , for example, we may define at least three kinds of independent scales for each sample of kelyphite: (1) the scale of spinel lamellae, i.e., the thickness of the lamellae or the average spacing of them; (2) the average size of the Cpx patches or the average spacing of them; and (3) the average size of the kelyphite domains (i.e., the Opx single crystal). (The thickness of the spinel lamellae and the average spacing of them are inter-related to each other via average modal compositions and hence are treated as one independent parameter for scale.) For Norwegian sample, for example, the average spacing of the spinel lamellae is about 1 micron; the average distance between $\mathrm{Cpx}$ patches, measured along circular direction of the kelyphite shell, is a few tens of microns; and the average Opx domain size is approximately hundreds of microns (Fig. 3b). The spacing of spinel lamellae, however, may differ for different domains even within a single body of kelyphite, but there is a clear tendency that it decreases inward toward the garnet (Fig. 3). There appear to be correlation between scales (1) and (2) and further, with inferred formation temperatures of the kelyphites; i.e. the higher the temperature, the coarser the grain size of the kelyphite (Obata \& Ozawa, 2011).

For Type 2, the comparable scale of (1) of Type 1 is the spacing of Opx lamellae, and (2) the size of Opx patches that contain vermicular spinels; and (3) the size of the large crystallographically coherent domains. In addition, for this type, the fourth scale may have to be introduced to characterize the ultra-fine spinel lamellae within the Opx patches (typically less than 1 micron; Fig. 4b).

\subsection{Structural similarity}

With the idea of the scales in mind it is interesting to compare the kelyphites with much coarser-grained pyroxene-spinel symplectites that occur in a high-temperature peridotite mass at Horoman, Japan (Takahashi \& Arai, 1989; Morishita \& Arai, 2003). Although the latter does not have a radial structure as kelyphites and does not contain relict garnets, it has been considered to be after garnet (Takahashi \& Arai, 1989; Morishita \& Arai, 2003; Obata et al., 1997; Odashima et al., 2008). Microstructure of the latter is very similar to that of a single domain of kelyphite although the scale is very different between the two (Fig. 6). Such structural similarity over different scales implies the existence of common physical processes of structural formation between the two. On the basis of the similarity and the topotaxic relationship as mentioned below, Obata \& Ozawa (2011) proposed that the coarse-grained symplectite such as observed in the Horoman symplectite is a special case of kelyphite, in which only one or two domains (or cells) of kelyphite were formed. The factor that dictates the number of domains (or cells) will be discussed in relation to the nucleation rate as below.

\subsection{Three-dimensional structure of spinel in the kelyphite}

The texture is usually observed only in two dimensions in sections and we only infer their three-dimensional (3D) structure from collections of the two-dimensional (2D) images. Morishita (2000) is an example of such efforts. Morishita et al. (2003) went a step forward by directly observing the 3D structure of spinels within the Horoman symplectite by means of 
Kelyphite and Symplectite: Textural and Mineralogical Diversities and Universality, and a New Dynamic View of Their Structural Formation

high-resolution X-ray CT (computed tomography), without physically slicing the rocks, and showed that the spinel, which appeared as discrete many grains within a pyroxene matrix, are in fact, connected to each other forming a large complex-shaped single grain of spinel (Fig. 7). On the basis of the similarity argument above, it is reasonable to suppose that the spinel grains in much finer-grained kelyphites are also continuous and are connected to each other over a long distance in three dimensions. The recognition of the continuity of spinel grains is important in the consideration of material transfer via grain-boundary diffusion as discussed below.

(a)

(b)

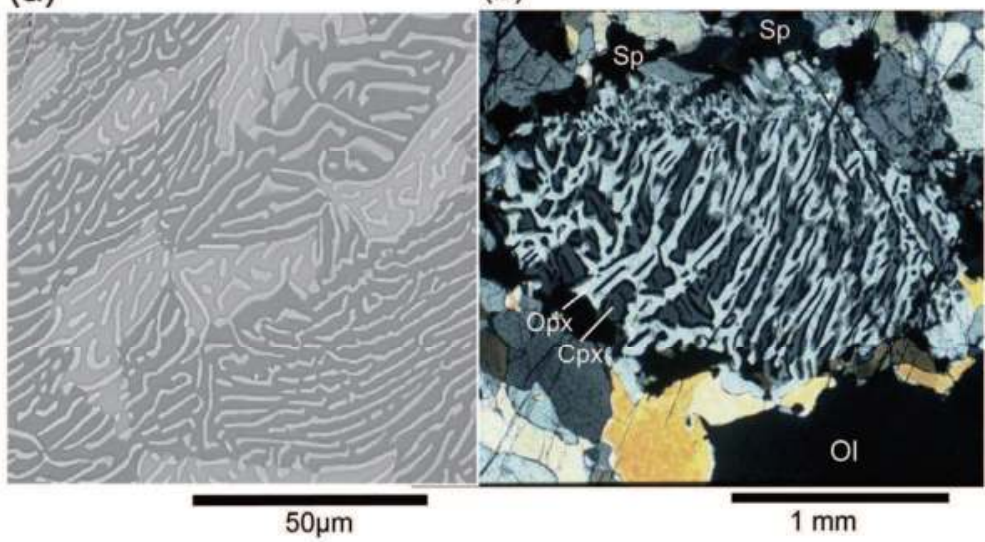

Fig. 6. Photomicrographs of (a) kelyphite from a Norwegian garnet peridotite (BSE image) and (b) pyroxene-spinel symplectite from Horoman peridotite (cross-polarized light) that show similarity in microstructure, despite of a large difference in scale between the two. (a) modified from Obata \& Ozawa (2011); (b) modified from Obata (2007)

(a)

(b)
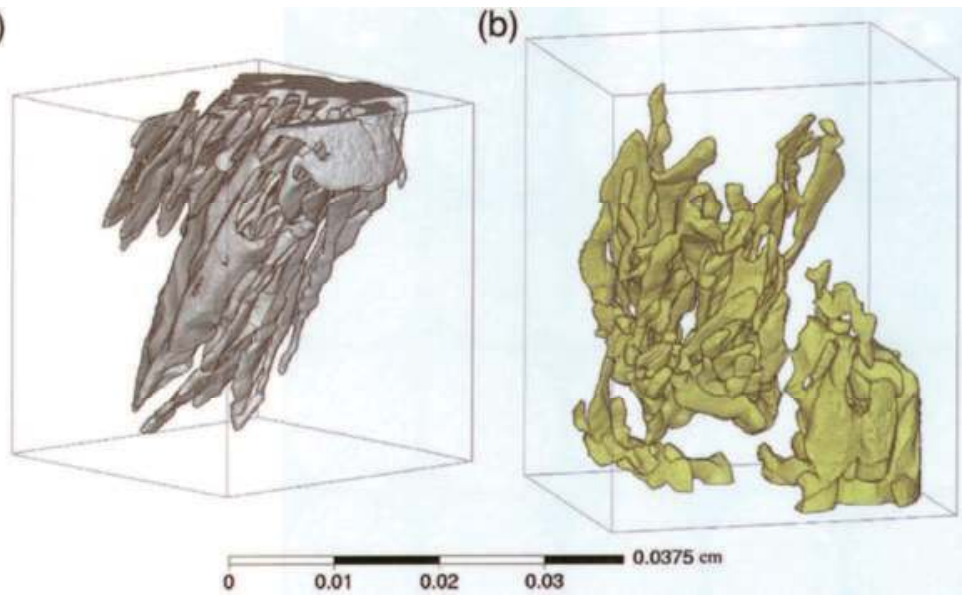

Fig. 7. 3D-images of two single grains of spinel from a pyroxene-spinel symplectite, Horoman peridotite, recovered by X-ray CT. After Morishita et al. (2003) 


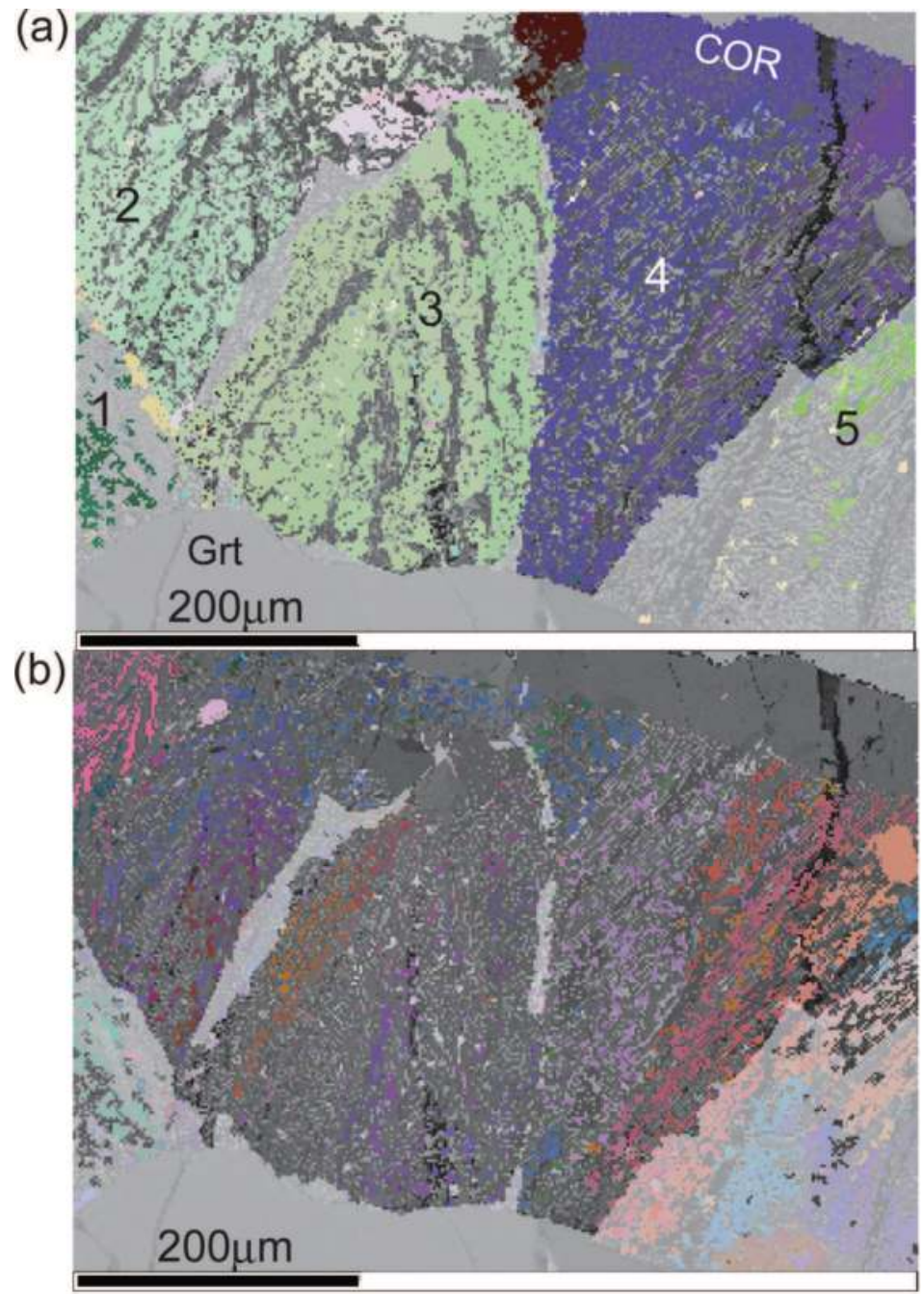

Fig. 8. Crystallographic orientation maps of Opx (a) and spinel (b) in kelyphite, Norwegian garnet peridotite (cf. Figs. 1 and 3a). Different colors represent different mineral orientations (Euler angles) determined by EBSD. Numbers label distinct Opx domains (a). Each Opx domain may be sub-devided into several spinel domains of different orientations (b). From Obata \& Ozawa (2011)

\subsection{Topotaxic relationships}

An important advance recently made in the science of symplectite is the recognition of crystallographic (topotaxic) relationships by means of EBSD (electron back-scattered diffraction analysis) among the constituent minerals in the kelyphites and symplectites (Odashima et al., 2008; Obata \& Ozawa, 2011). Their results are summarized as follows. It was shown for varieties of Type 1 kelyphites each kelyphite domain (or a cell) has a 
topotaxic relationship between Opx and Cpx by sharing their (100) and (010) and [001]. Two kinds of cells were recognized according to the topotaxic relationships between the spinel and pyroxenes: (1) topotaxic cells, in which one of spinel $\{111\}$ coincides with pyroxene (100) and one of spinel $\{110\}$ coincides with pyroxene (010); (2) non-topotaxic cells, in which such topotaxic relationship between the spinel and pyroxenes is incomplete or absent (Obata \& Ozawa, 2011). It appears that kelyphites that formed at relatively high-temperatures, such as Czech garnet peridotite from Mohelno (Kamei et al., 2010), $\left(>800^{\circ} \mathrm{C}\right)$ contain topotaxic cells; whereas those of lower-temperature origin $\left(<800^{\circ} \mathrm{C}\right)$, such as Norwegian garnet peridotites from Ugelvik, Otrøy Island (Spengler et al., 2006), dominantly consists of non-topotaxic cells (Fig. 8). The boundary between the high temperature and the low temperature appear to lie somewhere around $800^{\circ} \mathrm{C}$ according to the two-pyroxene thermometry (Taylor, 1998) applied to the kelyphite pyroxenes (Obata \& Ozawa, 2011). The spinel-pyroxene symplectite from the Horoman peridotite is regarded to represent a perfectly topotaxic cell that was formed after garnet at highest temperatures $\left(>950^{\circ} \mathrm{C}\right.$, Ozawa \& Takahashi, 1995; Ozawa, 2004) among the samples investigated.

It is interesting to note that a mother phase garnet does not have any particular crystallographic relationships with the adjacent pyroxene or spinel in the kelyphite so long as investigated (Obata \& Ozawa, 2011). The COR-Opx does not have any clear topotaxic relationship with adjacent olivines either, but it is possible that original relationship, if it ever once existed, may have been lost through plastic deformations of olivine and Opx as discussed below.

The EBSD analysis on the second type of kelyphite is in progress but preliminary analysis shows a constancy of crystallographic orientation of the lamellar Opx, thereby defining a different kind of domain structures from Type 1 and the same topotaxic relationship between Opx and spinel as observed in the Type 1 kelyphite. Garnet does not seem to have any topotaxic relationships with pyroxene or spinel like Type 1, which is in accord with the results obtained by transmission electron microscope (TEM) analysis for a Type 2 kelyphite in a garnet granulite xenolith (Dégi et al., 2010).

\subsection{Other varieties of symplectites and reaction correspondances}

Fig. 9 shows a few more examples of symplectites from totally different chemical systems. (a) and (b) are symplectites replacing garnets in ultrahigh-temperature felsic or pelitic granulites, in which quartz is excess. In (a), garnet is partly replaced with an Opxplagioclase symplectite, which is mounted in a matrix consisting of quartz and Cpx as primary phases (Sajeev et al., 2007). (b) shows a more complex texture where garnet is replaced with a spinel (hercynite)-plagioclase symplectite, which is further surrounded by a matrix consisting of coarse-grained spinel, plagioclase, alkali-feldspar, quartz, and sillimanite that is now altered to another kind of hercynite-plagioclase symplectite (Hiroi et al., 1997). These symplectites, except the one after sillimanite in (b), are clearly after garnet and both show radial structure like kelyphites; they are both called 'symplectite' in the original literature probably because of their coarse grain size. It is interesting to note that in (b) the grain size and the domain size of the Sp-plagioclase symplectite becomes suddenly much reduced near the garnet. Whether such a sudden change in microstructure is due to a temporal change of external physical conditions during the kelyphitization, such as the temperature change, or some internal and intrinsic mechanical control of structural development, is unknown and left to be studied. Note that, despite of such structural complexities, the fibrous structure of the symplectite yet tends to be normal to the reaction front of the garnet in both (a) and (b) no matter how strong the curvature of the boundary is. 


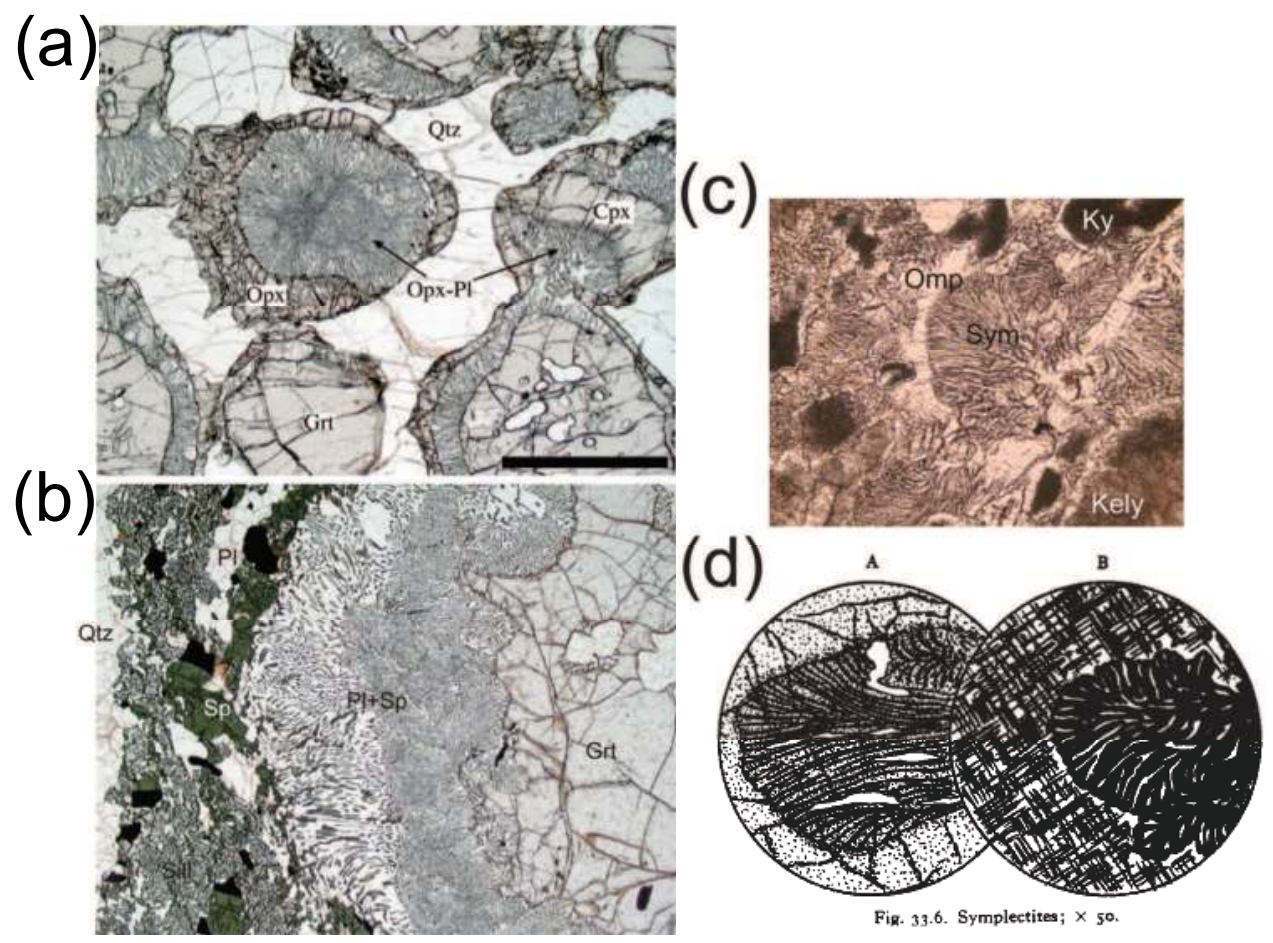

Fig. 9. Photomicrographs (plane-polarized light) and sketches of varieties of symplectites. (a) Opx-Pl symplectite after garnet, high-temperature granulite, Sri Lanka; (b) Pl-Sp symplectite after garnet in khondalite, Sri Lanka. 'Sill', Pl-Sp symplectite after sillimanite. Scale bar is $1 \mathrm{~mm}$ for both photographs (from Shuto and Osanai, 2002). (c) Cpx-Pl symplectite after omphacite (Omp), kyanite eclogite, Nové Dvory, Czech Republic. 'Sym', symplectite; 'Kely', kelyphite. 'Ky', Pl-Sp symplectite after kyanite. Width of the view is $1 \mathrm{~mm}$. (d) Sketches of (A) 'dactylitic' (finger-like) intergrowth of hypersthene, spinel and cordierite after garnet, Madras granulite and (B) Myrmekite (Pl-Qtz symplectite replacing microcline, cross-polarized light), Ardveen, Donegal. From Nockolds et al. (1978)

It is obvious from their mineral assemblages of the symplectites that significant material transfer had occurred upon the breakdown of garnet in both cases. In (a), the symplectite is enveloped by a rim of Opx like COR in the Type 1 kelyphite in the peridotite case, but the adjacent phase is quartz in (a) instead of olivine in the peridotite. From the configuration of the minerals the net reaction for the formation of the symplectite in this case may be inferred as:

$$
\mathrm{Grt}+\mathrm{Qtz} \rightarrow \mathrm{Opx}+\mathrm{An}
$$

or using mineral formulas:

$$
\begin{aligned}
& \left(\mathrm{Mg}_{2+x} \mathrm{Ca}_{1-\mathrm{x}}\right) \mathrm{Al}_{2} \mathrm{Si}_{3} \mathrm{O}_{12}+(1-x) \mathrm{SiO}_{2} \rightarrow \mathrm{Mg}_{2} \mathrm{Si}_{2} \mathrm{O}_{6} \cdot x \mathrm{MgAl}_{2} \mathrm{SiO}_{6}+(1-x) \mathrm{CaAl}_{2} \mathrm{Si}_{2} \mathrm{O}_{8} \quad(0<x<1) \\
& \text { Grt Qtz Opx An }
\end{aligned}
$$


This is an analogous reaction to a Ca-free version of reaction (1) as such:

$$
\mathrm{Grt}+\mathrm{Ol} \rightarrow \mathrm{Opx}+\mathrm{Sp}
$$

or

$$
\begin{aligned}
& \mathrm{Mg}_{3} \mathrm{Al}_{2} \mathrm{Si}_{3} \mathrm{O}_{12}+(1-x) \mathrm{Mg}_{2} \mathrm{SiO}_{4} \rightarrow(2-x) \mathrm{Mg}_{2} \mathrm{Si}_{2} \mathrm{O}_{6} \cdot x \mathrm{MgAl}_{2} \mathrm{SiO}_{6}+(1-x) \mathrm{MgAl}_{2} \mathrm{O}_{4} \quad(0<x<1) \\
& \text { Grt } \quad \mathrm{Ol} \quad \mathrm{Opx} \quad \mathrm{Sp}
\end{aligned}
$$

(MacGregor, 1974). It is noted that reactions (4) and (5) may be related to each other through a substitution of Qtz and An in the former with Ol and Sp in the latter, respectively. In much the same way as Cpx appears in the Ca-saturated system to form reaction (1) in the peridotite system, Cpx may appear to reaction (4) for appropriate compositions of garnet. A more generallize expression for reaction (4) allowing the appearance of Cpx may then be written as:

$$
\begin{array}{ccc}
{\left[(1-y) \mathrm{Mg}_{3} \mathrm{Al}_{2} \mathrm{Si}_{3} \mathrm{O}_{12} \cdot y \mathrm{Ca}_{3} \mathrm{Al}_{2} \mathrm{Si}_{3} \mathrm{O}_{12}\right]+(1-x) \mathrm{SiO}_{2} \rightarrow} & \\
\text { Grt } & \text { Qtz } \\
\left(\frac{2-3 y}{1+x}\right)\left[\mathrm{Mg}_{2} \mathrm{Si}_{2} \mathrm{O}_{6} \cdot x \mathrm{MgAl}_{2} \mathrm{SiO}_{6}\right]+\left(\frac{x+3 y-1}{1+x}\right)\left[\mathrm{CaMgSi}_{2} \mathrm{O}_{6} \cdot x \mathrm{CaAl}_{2} \mathrm{SiO}_{6}\right]+(1-x) \mathrm{CaAl}_{2} \mathrm{Si}_{2} \mathrm{O}_{8} \\
\text { Opx } & \mathrm{Cpx} & \begin{array}{c}
\mathrm{An} \\
(0<x<1,0<y<1)
\end{array}
\end{array}
$$

, where $x$ and $y$ represent the $\mathrm{Al}$ and Ca contents of pyroxene and garnet, respectively. As mapped for the coefficients of Opx and Cpx of the above reaction in the $x-y$ coordinate system (Fig. 10), Cpx has a negative value of coefficient in reaction (6) in Field A $(x+3 y-1<0)$ and thus appears as a reactant phase as:

$$
\mathrm{Grt}+\mathrm{Cpx}+\mathrm{Qtz} \rightarrow \mathrm{Opx}+\mathrm{An}
$$

or as a product phase in Field $\mathrm{B}(x+3 y-1>0,2-3 y>0)$ as:

$$
\mathrm{Grt}+\mathrm{Qtz} \rightarrow \mathrm{Opx}+\mathrm{Cpx}+\mathrm{An}
$$

or also as a product but with Opx as a reactant phase in Field $C(x+3 y-1>0,2-3 y<0)$ as:

$$
\mathrm{Grt}+\mathrm{Opx}+\mathrm{Qtz} \rightarrow \mathrm{Cpx}+\mathrm{An} .
$$

Reaction (7) coincides with the one originally proposed by Sajeev et al. (2007), which explains the Opx-Plagioclase symplectite also present between the garnet and primary Cpx. It is predicted that for more calcic garnets (Fields B and C in Fig. 10.), Cpx becomes a product phase and appear in the symplectite assemblage as in reaction (8), which is again analogous to reaction (1) in the peridotite system. The Cpx-free reaction (4) is a special case where coefficient of $\mathrm{Cpx}(x+3 y-1)$ equals zero (just at the boundary between the Fields $\mathrm{A}$ and B in Fig. 10).

Being guided by such 'correspondence principle', a similar operation may be made, by substituting $\mathrm{Ol}$ and $\mathrm{Sp}$ in reaction (5) with, this time, sillimanite and An, respectively, to obtain a new reaction for case (b) as:

$$
\mathrm{Grt}+\mathrm{Sill} \rightarrow \mathrm{An}+\mathrm{Sp}+\mathrm{Qtz}
$$


or

$$
\begin{aligned}
& (1-y) \mathrm{Mg}_{3} \mathrm{Al}_{2} \mathrm{Si}_{3} \mathrm{O}_{12} \cdot y \mathrm{Ca}_{3} \mathrm{Al}_{2} \mathrm{Si}_{3} \mathrm{O}_{12}+2 \mathrm{Al}_{2} \mathrm{SiO}_{5} \rightarrow 3 y \mathrm{CaAl}_{2} \mathrm{Si}_{2} \mathrm{O}_{8}+3(1-y) \mathrm{Mg}_{2} \mathrm{Al}_{2} \mathrm{O}_{6}+(5-6 y) \mathrm{SiO}_{2} \\
& \text { Grt Sill } \quad \text { An } \quad S p \quad \text { Qtz } \\
& (0<y<1)
\end{aligned}
$$

This may explain the observed sequence of minerals: Grt/ Pl-Sp symplectite/Sp/ An/Sill/, where Sp (outside the symplectite) and An correspond to the nodular spinel and COR-Opx, respectively in the kelyphite in the peridotite case (This is to suppose that sillimanite was a stable phase at the time of the reaction.) Note that for very calcic garnet (i.e., $y>5 / 6$ ), Qtz becomes a reactant phase as such:

$$
\text { Grt }+ \text { Sill }+ \text { Qtz } \rightarrow \text { An }+ \text { Sp }
$$

I here emphasize that different varieties of symplectites and kelyphites that are developed in chemically distinct systems may be interrelated and understood systematically with the aid of the 'correspondence principle' and 'substitution' operations for minerals, which makes the consideration for the mechanism of reactions for the peridotite case that will be given below more universal and applicable.

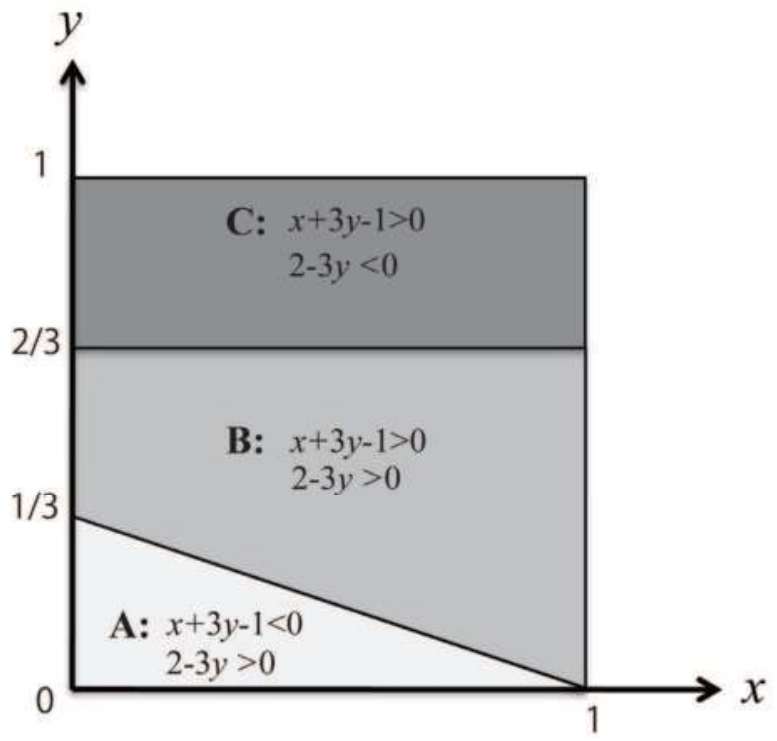

Fig. 10. Coefficients of reaction (6) shown in a $x-y$ diagram define three fields in the possible area $(0<x<1,0<y<1)$ : A, coefficient of $\mathrm{Cpx}$ is negative and that of Opx positive [reaction (7)]; $\mathrm{B}$, those of Cpx and Opx are both positive [reaction (8)]; C, that of Cpx is positive but that of Opx negative [reaction (9)]. See text for more details

Fig. 9c shows another well-known example of symplectite where omphacite is partly decomposed into assembly of diopsidic Cpx and albite as is typically observed in many eclogites worldwide (e.g., Vernon, 2004). The reaction front of the symplectite is typically concaved inward toward the omphacite. The fibrous structure of the symplectite diverges 
out against the curved front boundary so that the symplectite fibers are nearly normal to the reaction front, giving an internal structure of symplectite resembling a 'cauliflower'. The same texture but of different mineralogies can be found in a standard textbook of petrography (Nockolds et al., 1978) as reproduced in Fig. 9d. It is interesting to note that despite of the (morphological) curvature of the fibrous crystals of pyroxene and plagioclase they all show the same extinction angles respectively indicating that the crystal lattice did not change in orientation during the growth of the fibrous crystals as in the case of spinels in the kelyphites. This invariance of crystal lattice orientation during the crystal growth despite of their morphological curvature, within a single body of symplectite, is also held for the spinel strings in the kelyphite in peridotites, as verified by means of EBSD analysis. Such constancy of crystal lattice orientation may be said to be another common and universal feature of the kelyphite and symplectite.

In terms of bulk chemistry, since diopside and albite cannot make the omphacite composition it is apparent that the symplectite forming reaction is not isochemical and involved significant material transfer with surroundings. A possible expression for the reaction would be:

$$
\text { Omphacite }+\mathrm{SiO}_{2} \rightarrow \text { diopside }+ \text { albite }
$$

or

$$
\begin{array}{rcc}
\mathrm{CaMgSi}_{2} \mathrm{O}_{6} \cdot x \mathrm{NaAlSi}_{2} \mathrm{O}_{6}+x \mathrm{SiO}_{2} & \rightarrow \mathrm{CaMgSi}_{2} \mathrm{O}_{6}+x \mathrm{NaAlSi}_{3} \mathrm{O}_{8} \\
\mathrm{Cpx}_{1} & \mathrm{Cpx}_{2} & \mathrm{Ab}
\end{array}
$$

, where $\mathrm{SiO}_{2}$ represent a mobile component. Note that this reaction is also volume-increase.

\section{The Law of normality}

A tendency that the spinel fibrous structure is normal or perpendicular to the garnet grain boundary has previously been mentioned by many authors for many rock types (e.g., Godard \& Martin, 2000; Dégi et al. 2010). The same tendency is observed for symplectites after omphacite as mentioned above. It is so outstanding a tendency and appears to be universal that I decided to express it as a natural law - the 'law of normality'. It may be expressed in the following two ways (Fig. 11): (1) a geometric expression is "the kelyphite lineation is always normal to the garnet grain boundary (i.e., reaction front)". Whereas (2) $a$ kinematical expression would be that "the kelyphite growth direction coincides with the movement direction of the reaction front". Physically sound understanding of the origin of the law and the structural incoherencies (i.e., unconformities) as observed above must be founded on considerations on the reaction processes and the mechanism as discussed below. It should be remembered that the normality must have been held all the time during the breakdown processes of garnet, perhaps except at its earliest stages. Far from the garnet, the lineation is not necessarily normal to the present grain boundary. This means that the growth direction of the spinel lamellae has changed as crystals grew and that the reaction front has rotated accordingly so that the orthogonal relationship between the spinel lineation and the instantaneous reaction front that kept moving was always held (Fig. 12). The law of normality, however, does not apply to the initial garnet grain boundary, i. e., the boundary between the fine-grained kelyphite and the COR, to which the spinel lineation is typically oblique (Fig. 1, Fig. 3a, Fig. 5a). 

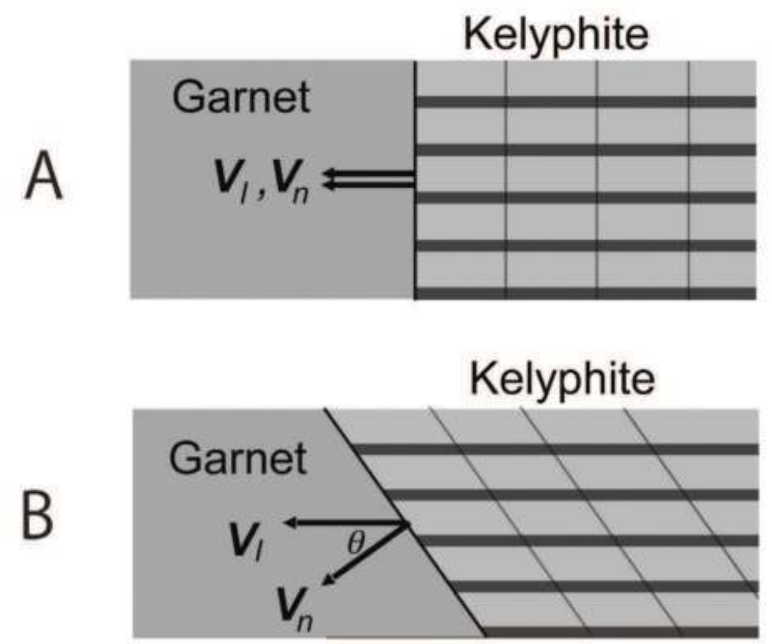

Fig. 11. Illustrations of the law of normality. $V_{1}$, velocity (vector) of the crystal growth of the fibors; $V_{\mathrm{n}}$ normal velocity of the reaction front. Two vectors coincide in case (A), but not in (B)

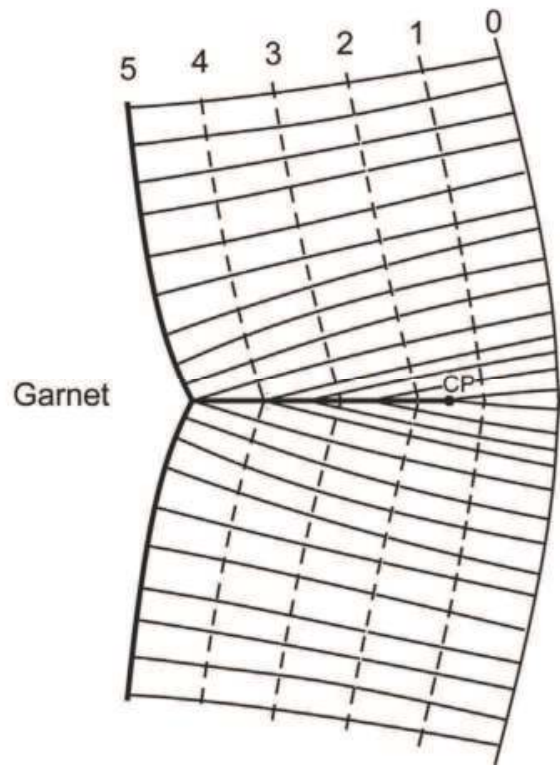

Fig. 12. A conceptual line drawing that shows how an 'unconformity' develops during kelyphite growth. Dashed lines labelled 1 to 4 represent imaginary isochronous garnet grain boundaries at different time slices in the past. The unconformity starts to form at a critical point $\mathrm{CP}$ and continues to a cusp on the present garnet grain boundary. Spinel lineations (thin solid lines) are always and everywhere normal to the isochronous lines (obeying the law of normality) 


\subsection{Application of the law of normality}

The power of the 'law of normality' proposed above may be demonstrated in an application of an attempt of tracing back the breakdown history of a single grain of garnet. Fig. 13a is a photomicrograph of a kelyphite that had completely replaced garnet, with highlighting the lineations and the 'unconformities' by line drawings. Being guided by the law of normality we can draw series of closed circuits that satisfy the law of normality as in Fig. 13b. Starting from an arbitrarily chosen point in the kelyphite region ( $\mathrm{P}$ in Fig. 13b), we may draw a closed circuit being guided by the law of normality, in such a way that the curve is orthogonal everywhere to the spinel lineation. Inflections must occur at each intersection with the 'unconformities' because of the discontinuous change of the lineation across the boundaries. Such a circuit represents an isochronous grain boundary of garnet at that instance; infinite numbers of such circuits may be drawn in much the same way as shown in Fig. 13b. The situation may be analogous to the geometrical relationship between the force (vector) field and its conjugate potential field, that consists of a set of equipotential surfaces, in continuum physics such as electromagnetic theory or fluid dynamics. Interestingly, the line density (or the spacing) of the circuits varies significantly according to the directions of the surfaces even along the same isochronous circuit: densely-spaced means a slower rate of growth (of kelyphite) than in a sparsely-spaced direction. Such apparent directional dispersion of the reaction rate becomes only visible by applying the law of normality, which raises an interesting question as to what controls the growth rate of the kelyphite. Certainly it cannot be ambient conditions such as temperature or lithostatic pressure. Local variations in the activity of $\mathrm{H}_{2} \mathrm{O}$ or in the deviatoric stress as mentioned below are other candidates to be further considered.

(a)

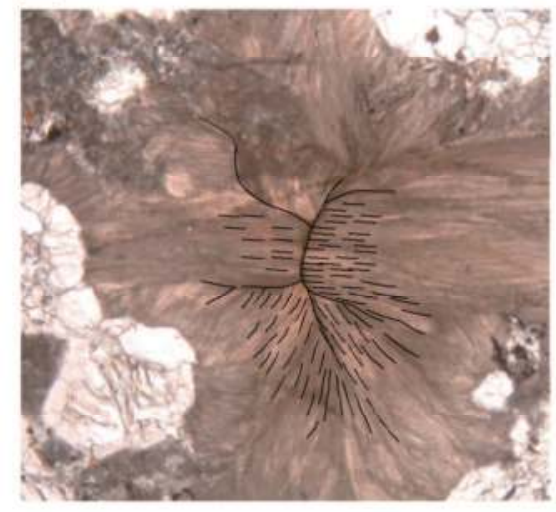

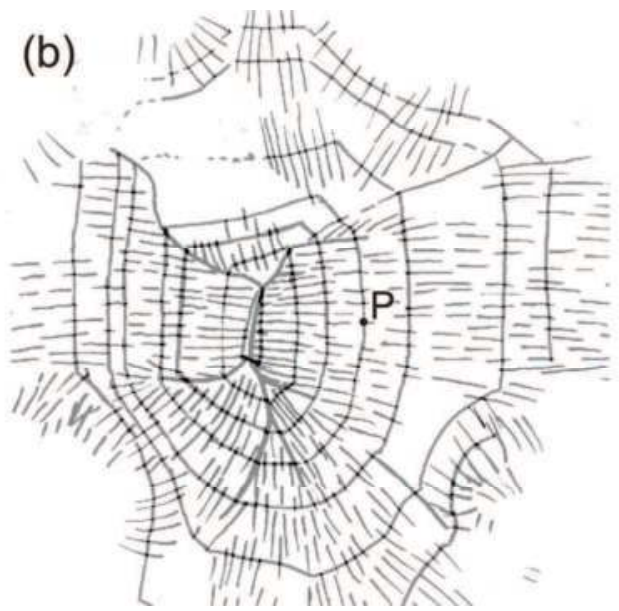

Fig. 13. Plane-polarized light photomicrograph (a) and corresponding line drawing (b) showing kelyphite domains and lineations used to reconstruct former (isochronous) garnet grain-boundaries by applying the law of normality. Width of the view (a) is $3 \mathrm{~mm}$. Sample from a garnet peridotite, Plešovice, Czech Republic

\section{Mechanism of the reactions}

Let us consider now the mechanism of reactions for the case of kelyphite of the first type (i.e., in the peridotitic system). It is well known that reaction (1) may take place upon 
decompression from the garnet peridotite stability field to the spinel peridotite stability field. Such expressions of reaction, however, does not explain the arrangement of minerals or mineral zones as observed in the kelyphite and, therefore, tells little about how reaction proceeds, i. e., the mechanism of reactions. Texturally the kelyphite zone appears to represent a replacement of original phase garnet; while the Opx rim (COR) in inferred to be after olivine. On such observational basis, we may envisage a reaction scheme as depicted in Fig. 14. Thus, reaction (1) may be written being splitted into the following two metasomatic reactions:

$$
\begin{gathered}
\text { Grt }+\alpha \rightarrow \text { Opx }+ \text { Cpx }+\mathrm{Sp}+\beta \\
\mathrm{Ol}+\beta \rightarrow \mathrm{Opx}+\alpha
\end{gathered}
$$

, where $\alpha$ and $\beta$ represents hypothetical mobile components or groups of components that may be produced or consumed at the reaction fronts in the discontinuous reactions. Reaction (13) occurs defining a reaction front against garnet (FR1 in Fig. 14); while reaction (14) occurs defining another reaction front against olivine (RF2, ibid). There should be an exchange of these components between the two reaction fronts across the reaction zone. A dominant mode of mass transfer across the reaction zone is probably the grain boundary diffusion and not the volume diffusion (i.e., Joesten, 1991). Components $\alpha$ and $\beta$ may be identified by mass balancing given the compositions of each mineral and only when the reference frame is specified (Thompson, 1959). In the following we treat a reaction in a simplest Ca-free system, $\mathrm{MgO}-\mathrm{Al}_{2} \mathrm{O}_{3}-\mathrm{SiO}_{2}$, to understand the essence of the physical mechanism of the reactions.

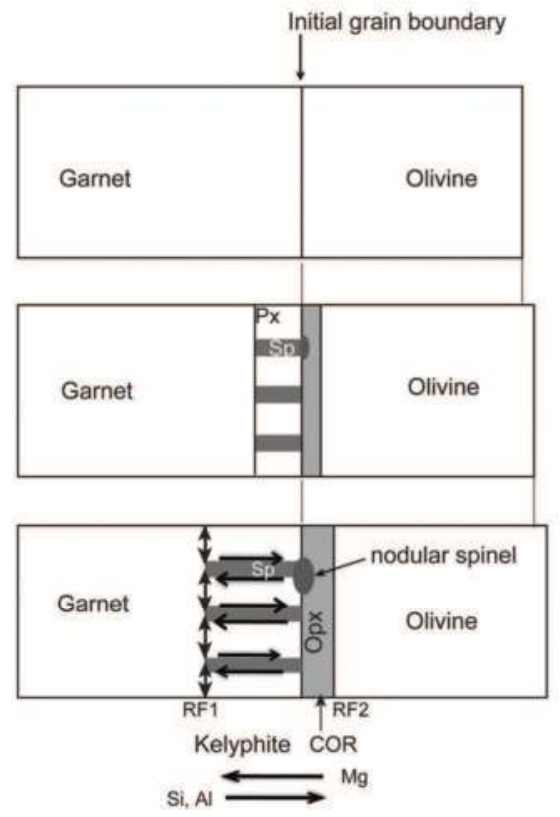

Fig. 14. One-dimensional growth model of kelyphite between garnet and olivine. RF1 and $\mathrm{RF} 2$ are reaction fronts on the garnet and olivine side, respectively. Px, pyroxenes (Opx and Cpx, not differentiated) 


\subsection{A model consideration in the $\mathrm{MgO}-\mathrm{Al}_{2} \mathrm{O}_{3}-\mathrm{SiO}_{2}$ system}

A model reaction correspond to reaction (1) in the $\mathrm{MgO}-\mathrm{Al}_{2} \mathrm{O}_{3}-\mathrm{SiO}_{2}$ system would be again:

$$
\begin{aligned}
& \mathrm{Mg}_{3} \mathrm{Al}_{2} \mathrm{Si}_{3} \mathrm{O}_{12}+(1-x) \mathrm{Mg}_{2} \mathrm{SiO}_{4} \rightarrow(2-x) \mathrm{Mg}_{2} \mathrm{Si}_{2} \mathrm{O}_{6} \cdot x \mathrm{MgAl}_{2} \mathrm{SiO}_{6}+(1-x) \mathrm{MgAl}_{2} \mathrm{O}_{4} \quad(0<x<1) \\
& \text { Grt Ol Opx } \mathrm{Op}
\end{aligned}
$$

where $\mathrm{x}$-the $\mathrm{Al}$ content of Opx-is determined by pressure and temperature condition of equilibrium (e.g., Wood \& Banno, 1973). Accordingly, Ca-free versions of reactions (3) and (4), respectively, may be written, using the oxygen-fixed reference frame, as:

$$
\begin{array}{cccc}
3 \mathrm{Mg}_{3} \mathrm{Al}_{2} \mathrm{Si}_{3} \mathrm{O}_{12}+2(1-x) \mathrm{Mg}^{2+} \rightarrow(4-x) & \mathrm{Mg}_{2} \mathrm{Si}_{2} \mathrm{O}_{6} \cdot 3 x \mathrm{MgAl}_{2} \mathrm{SiO}_{6}+3(1-x) & \mathrm{MgAl}_{2} \mathrm{O}_{4}+(1-x) \mathrm{Si}^{4+} \\
\mathrm{Grt} & \mathrm{Opx} & \mathrm{Sp} & \\
& & & (0<x<1)
\end{array}
$$

and

$$
\begin{array}{cc}
3 \mathrm{Mg}_{2} \mathrm{SiO}_{4}+\mathrm{Si}^{4+} \rightarrow \underset{2}{2} & \underset{\mathrm{Mg}_{2} \mathrm{Si}_{2} \mathrm{O}_{6}}{ }+2 \mathrm{Mg}^{2+} \\
\mathrm{Ol} & \mathrm{Opx}
\end{array}
$$

Note that number of oxygen is conserved in solid phases for both reactions. A linear combination of reactions (15) and (16) yields a net reaction $\left(5^{\prime}\right)$ making a system closed. Note that reactions $\left(5^{\prime}\right)$ and $(15)$ are all volume-increase ones (for $\mathrm{x}=0, \Delta V\left(5^{\prime}\right)=8.63 \mathrm{~cm}^{3}, \Delta V(15)=$ $31.02 \mathrm{~cm}^{3}$ or $\left.9.13 \% \mathrm{Grt}\right)$, whereas reaction (16) is volume-decrease $\left(\Delta V(16)=-5.13 \mathrm{~cm}^{3}\right.$ or $-3.92 \%$ olivine) (molar volume data of minerals used are listed in Appendix 1).

A physical picture of the reaction is then drawn as follows: garnet reacts at the reaction front with $\mathrm{Mg}^{2+}$ being supplied from the olivine side, with pyroxnene and spinel precipitating, replacing $\mathrm{Si}^{4+}$, which is instantaneously removed from this site and transferred toward the olivine side (Fig. 14). The olivine on the other hand is being replaced by Opx reacting with $\mathrm{Si}^{4+}$ and releasing $\mathrm{Mg}^{2+}$. The boundary between the kelyphite and COR represents the original garnet-olivine grain boundary. At reaction front RF1, garnet is constantly replaced with the intergrowth of pyroxene and spinel (i.e., kelyphite) and hence segregation occurs and material must be reorganized by a short-range material transfer along the garnet grain boundary in the tangential directions (Fig. 14). The scale of the intergrowth (or the spacing of the spinel lamellae) must be governed by the element mobility or diffusivity along the garnet grain boundaries relative to the (one-dimensional) migration rate of the reaction front, i.e., the growth rate of the kelyphite. At higher temperatures, the diffusion would become faster because diffusivity increases exponentially with temperature and thus coarser-grained kelyphites (or symplectites) would result. It is emphasized that discontinuous reactions occur only at the reaction fronts, RF1 and RF2 in this model, and the produced kelyphite zone works only as a medium for diffusional transport of elements. A dominant mechanism of this long-range axial material transfer is, as mentioned above, would be the grain boundary diffusion. Diffusion agent is not clear but if water or fluid is present along the grain boundaries, even in a trace amount, the diffusion would be greatly facilitated. Local variation in the extent of the kelyphitization of garnet as frequently observed in nature suggests that a fluid is taking a critical role in governing the rate of kelyphitization reactions.

It should be noted that, in reaction (15), $\mathrm{Al}$ is conserved as well as oxygen is and, therefore, no loss or gain of $\mathrm{Al}$ results. Mass balance analysis using actual analyses of garnets and bulk 
compositions of natural kelyphites, however, suggest that a significant loss of $\mathrm{Al}$ occurred from garnets upon the breakdown reactions, which means a flux of $\mathrm{Al}$ away from the reaction front of garnet side (RF1) (see Appendix 2; Obata \& Spengler, in preparation); this inconsistency may be reconciled by considering the growth of the nodular spinel as a sink of $\mathrm{Al}$, as discussed below.

\section{The volume problem}

The lineation structure normal to the reaction front (on the garnet side) would be a favorable one considering the efficiency of material transfer by grain-boundary diffusion. But such consideration is not enough to account for the origin of the 'law of normality'. More tight, some sort of physical constrains must be operative to control the orientation of the crystal growth. I envisage, for the origin of such hypothetical strong controlling force, the excess stress that may be generated at the reaction front. The discontinuous reaction such as reaction (15) is volume-increase. Remember that the kelyphite is a solid material consisting of pyroxenespinel symplectites armoring the garnet as a 'shell'. Free volume increase is therefore not possible inside the kelyphite shell (Fig. 15). Rather, the volume may be kept constant through the transformation reactions, for which some material must flow out of the system.

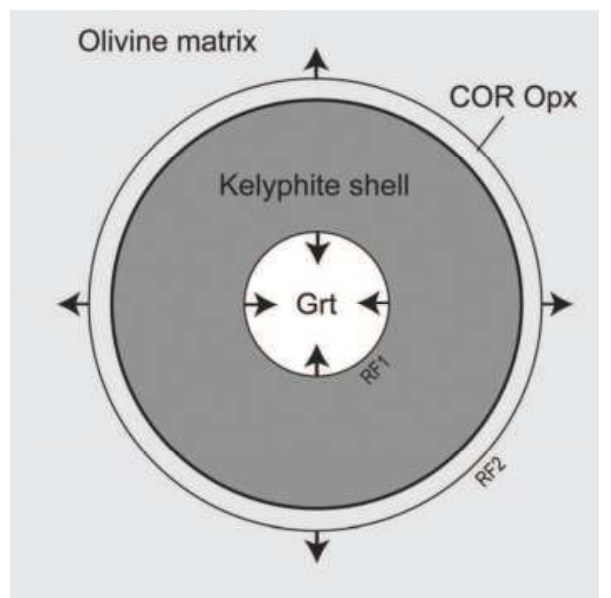

Fig. 15. Schematic illustration showing the inward growth of a kelyphite shell and the outward growth of COR

One possibility to meet the volume constant requirement is, considering the presence of the nodular spinel at the kelyphite-COR boundary, to split the spinel in reaction (15) into two parts as such:

$$
\begin{gathered}
3 \mathrm{Mg}_{3} \mathrm{Al}_{2} \mathrm{Si}_{3} \mathrm{O}_{12}+2(1-x) \mathrm{Mg}^{2+} \rightarrow \\
\mathrm{Grt} \\
\begin{array}{c}
(4-x) \mathrm{Mg}_{2} \mathrm{Si}_{2} \mathrm{O}_{6} \cdot 3 x \mathrm{MgAl}_{2} \mathrm{SiO}_{6}+3(1-x)\left[(1-p) \mathrm{MgAl}_{2} \mathrm{O}_{4}\right. \\
\text { kelyphite }
\end{array} \\
\begin{array}{c}
\text { nodular spinel } \\
\text { ngAl }
\end{array} \\
(0<x<1,0<p<1)
\end{gathered}
$$


, where $p$ is a new parameter introduced for partitioning of spinel between inside the kelyphite shell and the nodular spinel just outside the shell. It is possible to adjust coefficient $p$ so that the volume change at the reaction front to be zero. The idea is to suppose that spinel is partly segregated out of the kelyphite shell. This idea is depicted schematically in Fig. 16, where the size of the kelyphite shell is kept constant during the progress of kelyphitization. The volume increase of reaction (15) or (17) is accommodated outside the kelyphite shell by the growth of the nodular spinels. Although reaction (16) is volume decrease, sum of the nodular spinel and the COR must expand in volume since reactions (1) and (5) are volume-increase. This net volume increase may be accommodated by plastic deformation of surrounding olivines.

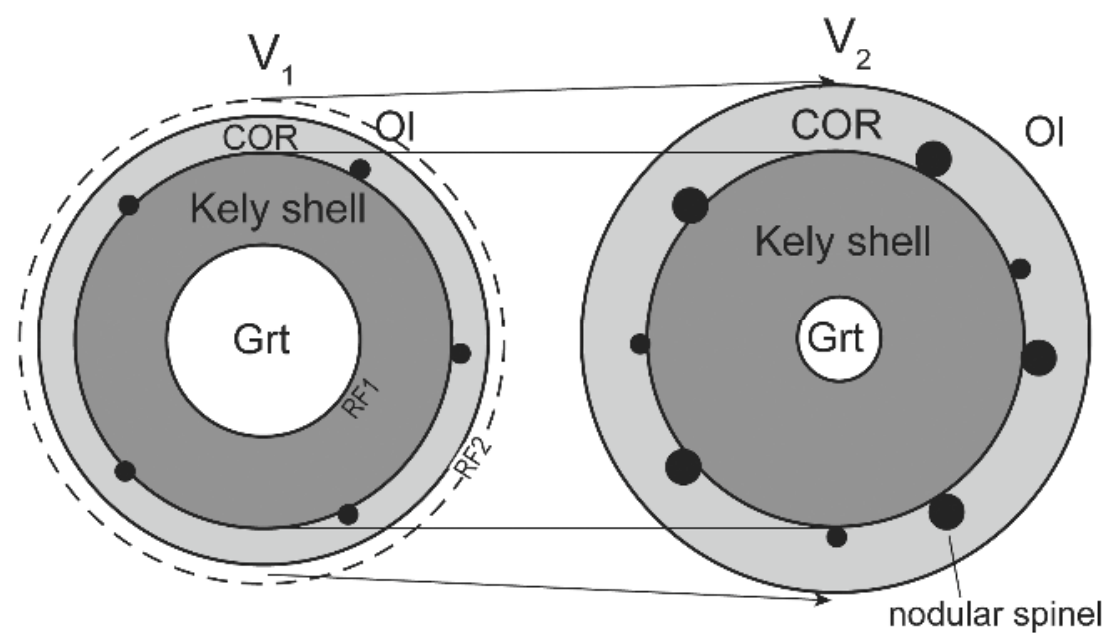

Fig. 16. Sketch that illustrates the volume change associated with the kelyphitization of garnet. The diameter of the kelyphite shell remains constant during shrinkage of garnet and growth of nodular spinel and COR. Volume $V_{1}$ that includes surrounding olivine expands by consuming peripheral olivine to another volume $V_{2},\left(V_{2}>V_{1}\right)$ in which the total mass included is conserved (closed system). Scales exaggerated and not proportional

\section{Generation of the internal stress and the origin of the law of normality}

In the light of the above view, it is conceivable that the reaction front on the garnet side (RF1) is constantly be subjected to a considerable stress during the growth of kelyphite, which may contribute in part to the driving force of outward flow of material. Because the surface area of the reaction front is virtually constant for a small increment of the reaction progress, the generated internal stress should be compressional tangentially to the reaction front surface, i.e., maximum principal normal stress being tangential. It is well known that bulk elastic modulus of lamellar structure that consists of materials of different elastic moduli is minimum in the normal direction of the lamination, therefore, elastic potential near the reaction front region is minimized for the normal configuration, proving that this is mechanically the most stable geometry. I, therefore, interpret that such non-hydrostatic stress being generated constantly on the moving reaction front is the main force that controls 
and guide the growth direction of the kelyphite lamellar structure. I should like to emphasize here that the Cpx patches enclosed in the kelyphite-Opx are not necessarily elongated like spinels and hence does not appear to obey the law of normality. The contrast of the elastic moduli between Opx and Cpx is much less than that between pyroxene and spinel (Anderson et al., 1968), and therefore morphology of the Cpx patches should be less sensitive to the stress field than for the spinel lamellae. Such considerations on a morphological contrast between the pyroxene and spinel substantiate the author's hypothesis for the origin of the law of normality.

The law of normality may be realized in any other reaction system, in which volume increase is involved. Examples include symplectite after omphacite as mentioned above, or even, myrmekite, a symplectite intergrowth of quartz and plagioclase replacing K-feldspar, typically developed in granitic systems (Fig. 9d).

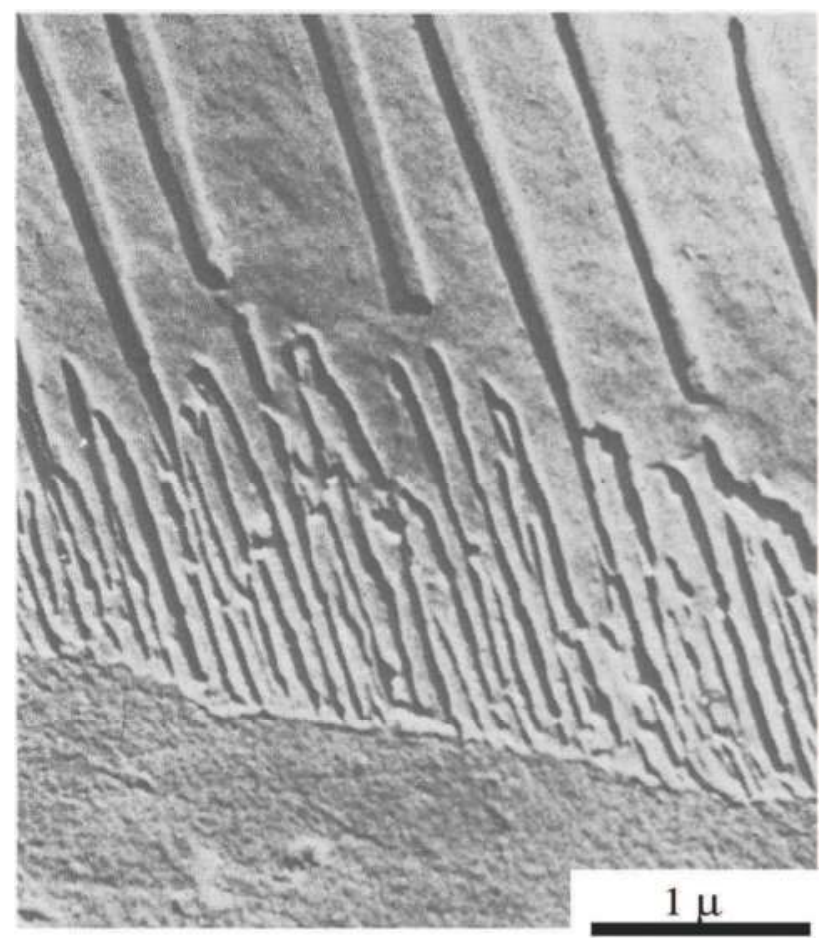

Fig. 17. Secondary electron micrograph of low-alloy steel partially transformed to pearlite at $700^{\circ} \mathrm{C}$ for 15 minutes and then quenched. Finer-scaled pearlite near the transformation front was probably created by a rapid growth during the quenching. Note oblique angle of the pearlite structure to the transformation front. From Darken and Fisher (1962) Figure 2, used with permission

\subsection{Implications from a steel microstructure, pearlite}

Similar textures as symplectites has been known in metallurgy and are well studied for industrial purposes (Darken \& Fisher, 1962; Chadwick, 1972). Fig. 17 shows a typical texture 
of pearlite - a eutectoidal texture of steel. Such texture may be artificially produced by cooling a Fe-C alloy, austenite, which may decompose into two phases of different compositions, ferrite and cementite, by an eutectoidal reactions. The produced lamellae are typically straight and the spacing may be artificially controlled by changing the cooling rate. This is an important industrial technique to control the microstructure and thereby adjusting the mechanical strength of the steel. Note that the lamella structure is oblique to the reaction front in this case so that the law of normality does not appear to be held here. The transformation is temperature-induced for the alloy and not decompression-induced like kelyphite in rocks, which implies that the enthalpy change is more important than the volume change for the transformation reaction for the steel (Hillert, 1962). If volume change is not significant, internal stress will not be significant either. The absence of the normality in steel, therefore, supports the author's hypothesis for the role of internal stress to account for the origin of the normality for volume-increase transformation reactions.

\section{A synthesis - a new view of the kelyphite formation}

Summing up the knowledge and considerations above we may now draw a new and dynamic picture of the formation and growth of the kelyphite, of the first type.

\subsection{Kelyphite cells and a colony}

It was pointed out above that each 'cell' of kelyphite may be regarded to represent a growth unit of a kelyphite. A body of kelyphite typically consists of many 'cells', and for this reason, it may be viewed as a 'colony' (Fig. 18) in the sense that it represents a macroscopic growing unit of organism. In three dimensions, these cells will be tubular in shape and gather forming a honeycomb-like structure as a colony. Different from typical colonies of livings like corals, however, this colony grows inward consuming garnet inside. The cell has its internal structure and functions. The base (or the matrix) of the cell is an Opx single crystal throughout; the cell is composed of two parts: (a) fined-grained fibrous part (i.e., kelyphite, sensu stricto) that contains many fine fibers of spinel and several small patches of Cpx dispersed in the Opx crystal, and (b) a clear part, COR, that is free of spinel fibers (Fig. 18). Nodular spinels may or may not reside at or around the junction of the two parts (a) and (b). The tubular cell has a distinct polarity in such a way that part (a) grows inward 'eating' garnet on one end, while part (b) grows outward 'eating' olivine. The growth of the cell is accompanied with the intra-cellular flow of material along the axial direction of the tubules. Important flow from (b) to (a), i.e., from the olivine side toward the garnet, is $\mathrm{Mg}^{2+}$; while important counter flows are $\mathrm{Al}^{3+}$ and $\mathrm{Si}^{4+}$. Part of the $\mathrm{Al}^{3+}$ however may be consumed at or near the junction of the two parts for the growth of the nodular spinel. The mechanism of such intra-cellular migration of material is probably the grain boundary diffusion along the surfaces of the spinel fibers. Continuation of spinel fibers along the length of the cell is therefore a necessary geometry. As mentioned above, the stress built up during the growth of kelyphite will increase the elastic potential energy of the kelyphite and may hold back and eventually stop the reaction. This increase of internal energy can be adjusted by a material flowing out of the kelyphite shell and by the volume expansion in part (b), which is allowed by plastic deformations of COR and the outer olivine matrix. It is conceivable, therefore, that the growth of the kelyphite 'colony' as a whole is controlled by the rate of stress release via plastic deformation of the surroundings which is manifested in ductile 
flow of rocks in a macroscopic scale. It is noted that some tubular cells may shrink and eventually extinct as the colony grows inward (Fig. 18) - a process known as the geometrical selection (Grigoriev, 1965).

Kelyphite colony

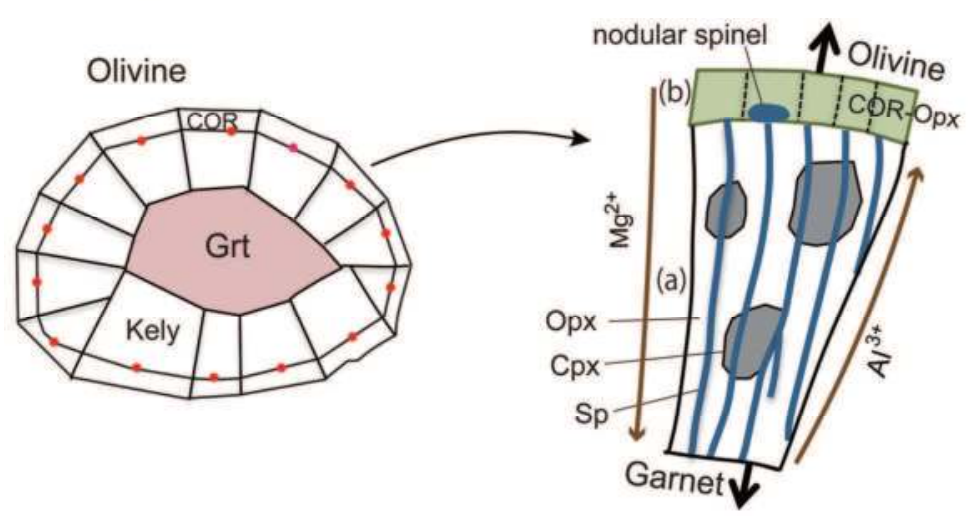

Fig. 18. Conceptual pictures of a kelyphite 'colony' composed of several tubular cells (left) and of the internal structure of a 'cell' and its functions (right). Red spots on the left figure indicate where nucleation of the cell occurred

\subsection{Origin of the topotaxy and the nucleation of the cell}

We have concerned so far a steady growth of the cell and a colony. The crystal of Opx containing fibrous spinels grow basically in two directions starting from its original site of birth probably at the junction of the two parts (i.e., the original grain boundary between garnet and olivine) as indicated with red points in Fig. 18. The growth of the nodular spinel is the extension of the growth of the fibrous spinels at their ends. The formation the Cpx patches is the only exception. The Cpx patches are discrete and are not likely to be connected to each other. So nucleation of Cpx occurs sporadically and intermittently but at the reaction front during the growth of the cell. The nucleation of the Opx and spinel, however, is considered to have occurred just once, at the birth of the cell, which is defined as the 'nucleation' of the cell. The topotaxic relationship between the spinel and Opx must therefore be established at their nucleation stage and the original nature of the topotaxy is simply inherited during the subsequent growth of the cell.

I then draw a detailed picture of the 'cell nucleation' for the kelyphite in garnet peridotites, and present a hypothesis how the topotaxic relationship may be acquired according to the scenario presented in Obata \& Ozawa (2011). Suppose a kelyphite starts to grow upon decompression of mantle rocks within the stability field of spinel peridotite. The kelyphitization starts at original grain boundaries between garnet and olivine by reaction (1). It is unlikely, however, that all the product phases, Opx, Cpx and spinel, nucleate together exactly at the same time. Considering the Opx domain structure, it is inferred that Opx is the first phase to nucleate and that each Opx domain grows from a single nucleus of Opx (Fig. 19). The nucleation and growth of Opx out of garnet will induce subsequent nucleation of spinel in a similar manner like eutectoidal because the Opx cannot take all the 
Al from the garnet (e.g. Putnis, 1992). Different from eutectoidal, however, the formation of spinel requires olivine to participate by reaction (1). Necessary material for the spinel nucleation (by reaction (15)) must be created by the conversion of olivine to Opx (COR) by reaction (16) and supplied to the site through the transfer of $\mathrm{Mg}^{2+}$ and $\mathrm{Si}^{4+}$. Because the COR-Opx grows from the common nuclei of Opx, it is natural that they are continuous and share the same crystallographic orientation forming even a larger domain of single crystal of Opx (Fig. 19). Because the spinel nucleation most likely occurs on the surface of Opx (because of the presumed large activation energy for the nucleation due to high surface energy, i.e. heterogeneous nucleation, it is likely that the crystallographic orientation of spinel will be dictated by that of Opx, resulting in a topotaxic relationship between the two phases. The activation energy for the nucleation of such spinel is considered to be very high because of the coupled nature of the reactions via element diffusional exchange between the two sites. Once nucleation occurred, the Opx-spinel assembly simply grows eutectoidally, replacing garnet, maintaining the topotaxic relationship initially established at the nucleation site. The lack of topotaxic relationship as observed in lower temperature samples such as the Norwegian ones (Obata \& Ozawa, 2011) suggests that the initial establishment of such topotaxic relationship may fail in nature in some circumstances.

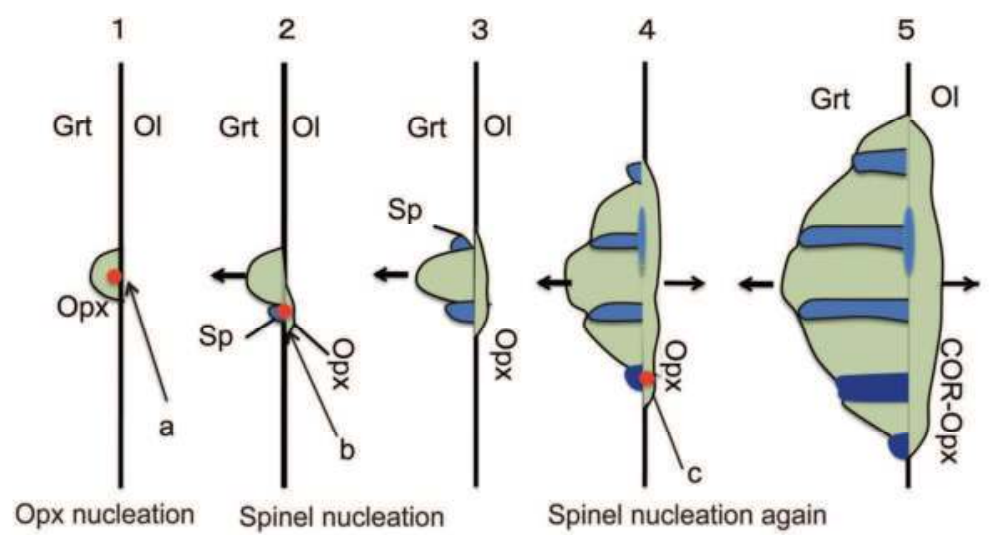

Fig. 19. Schemitic picture illustrating nucleation and subsequent eutectoidal growth of a kelyphite cell. (1) Opx initially nucleates at the original grain boundary (at point ' $a$ ') and starts to grow toward garnet; (2) spinel nucleates at a three-phase junction: Grt-Opx-Ol (at point ' $b^{\prime}$ ), consuming garnet and converting olivine to Opx (incipient COR); (3) spinel drawn on the other side of Opx is meant to be a continuation of the first nuclei; (4) the second and more nucleation of spinel may occur at separate spots on the original grain boundary (at point ' $c$ '); (5) the composite cell keeps growing by the eutectoidal processes. Spinels of different tones of blue color are meant to be derivatives from different nuclei

The number of nuclei formed at the transformation may be related with the nucleation rate (i.e., the number of nuclei generated per unit time), which must be a function of the degree of supersaturation (i.e., overstepping the equilibrium). This is schematically illustrated in Fig. 20. Theoretically, nucleation rate should be zero at equilibrium where the driving force of the reaction is zero and should increase with the degree of supersaturation. The pyroxene-spinel symplectite of the Horoman peridotite, which typically consists of single domain of Opx, is therefore considered to be a special case of kelyphite, where nucleation 
rate is so low that only one nucleus was formed for each grain of garnet. Because of the relatively high-temperature environment of the Horoman peridotite $\left(>950^{\circ} \mathrm{C}\right.$, Ozawa \& Takahashi, 1995; Ozawa, 2004), the reaction probably took place near the garnet-spinel transition boundary, without much delay and, therefore, with a minimum degree of supersaturation. Grain size (or spacing of the spinel and pyroxene lamellae) is probably mostly governed as mentioned above by diffusion of cations along the reaction front (i.e., garnet grain boundary), which is normal to the lamellae structure. At higher temperatures elements diffuse faster and hence coarser-grained symplectite would result. The decreasing order of the spatial scale of symplectite (or kelyphite) is, Horoman, Czech (Mohelno), and then Norway, which accords with the descending order of the inferred transformation temperatures (Obata \& Ozawa, 2011).

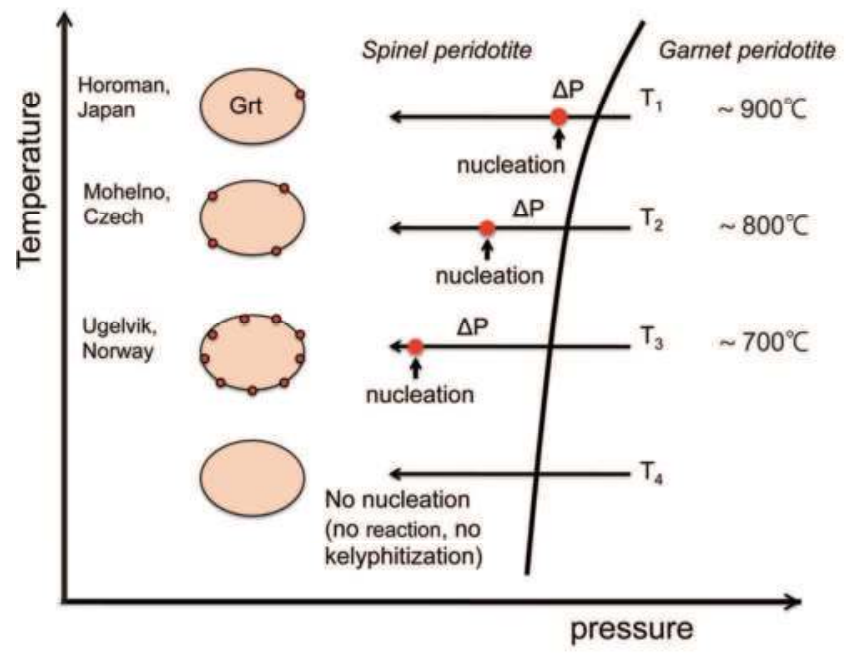

Fig. 20. A schematic picture illustrating in a $P-T$ space the relationships between the nucleation rates, topotaxic relationships and the degree of supersaturation upon decompression, which may be related to the temperature of transformation. Nucleation is delayed at lower temperatures, thereby producing more nuclei of the cells having disordered topotaxy. When temperature is too low, kelyphitization reaction will not occur

In the Czech (Mohelno) sample, the same topotaxic relationship as in the Horoman sample is held for all cell nuclei at the nucleation stage; while in the Norwegian sample, probably because of the substantially low-temperature of transformation $\left(740-760^{\circ} \mathrm{C}\right.$, Obata \& Ozawa, 2011), and hence because of the slower diffusion kinetics, the nucleation must have been delayed, and therefore, the degree of supersaturation must have become substantially large. Under such high degrees of supersaturation, when nucleation occurred, it is so rapid that many spinel nuclei will fail to gain topotaxic relationships with their host pyroxenes. The observed subdomain structure of spinel in the Norwegian kelyphite (Opx) cell (Fig. 8b) indicates that multiple nucleation of spinel probably occurred in a single growing cell of Opx (Fig. 19).

It is emphasized here that the internal structure of the cell is being created only at the reaction front and is instantaneously fixed behind as the reaction front sweeps away, except for the growth of nodular spinels. This is analogous to an 'ink-jet printer' which prints 
papers only at a printer head. Formation of Cpx patches also occur only at the reaction front (though not shown in Fig. 19). These Cpx seem to always gain topotaxic relationships with the host Opx at every time of their nucleation. However, if the rocks are kept at high-enough temperatures for a long time, coarsening may occur in the kelyphites as observed in the pyroxene-spinel symplectite of Horoman peridotite (Obata et al., 2007). Coarse vermicular intergrowth of pyroxene and spinel as observed in some spinel peridotite xenoliths (Marcier \& Nicolas, 1975; Smith, 1977) may be an end product of such recrystallization processes at high temperatures (Godard \& Martin, 2000). Such a scheme presented above may open up a new way of studying and understanding the variability of textures and the topotaxic relationships in relation with the geodynamic environments of the host rocks.

\section{Summary of conclusions}

Important conclusions drawn from the study of kelyphite of the first type may be summarized as follows:

1. A body of kelyphite may be regarded as a 'colony' composed of multiple tubular 'cells'. Each cell has its particular internal structure and functions, of growing in the expense of garnet on one end and in the expense of olivine on the other via the intra-cellular flow of material. The internal structure of the cell is created at the reaction front and is basically fixed behind the front except the growth of nodular spinels.

2. The law of normality is proposed for the spinel lineation and it was suggested that the normality is originated by the non-hydrostatic stress that is supposed to be generated at the reaction front by the volume increase reaction.

3. Topotaxic relationship may or may not be acquired at the stage of nucleation of the cells and the nature of the topotaxy is inherited during the subsequent growth of the cells.

4. The degree of perfections of topotaxy appears to be related with the temperature of transformation, which may further be related with geodynamic environments such as $P-T$ paths and the exhumation rate of the host rocks.

It was shown that different varieties of kelyphites and symplectites, of minerlogically and chemically different systems, may be interrelated through a mathematical operation called substitution and transformation, being guided by the 'correspondence principle'; such method may open up a new way of understanding natural diversities of metamorphic reaction textures in a more unified way.

\section{Acknowledgments}

I would like to thank Dr. Kazuhito Ozawa for his collaboration throughout the project but am solely responsible for possible errors in the interpretations if any. I also thank Dirk Spengler, Kosuke Naemura, and Dr. Y. Osanai and Dr. K. Hiroi for their providing valuable samples. I thank Dr. H. Nagahara (Univ. Tokyo) for her permission of the use of FE-SEM and EBSD at Univ. Tokyo and Dr. H. Yoshida and Mr. H. Tsutsumi for their technical assistance, and to Dr. T. Morishita and Ryoko Nagashima (both Kanazawa Univ.), A. Toramaru, T. Nishiyama, I. Shimizu for their discussions at various stages of the research. Thanks are extended to K. Naemura, T. Ueda and D. Spengler who proof-read the manuscript and giving me valuable comments. I am grateful to Ms. A. Pantar for her invitation for the volume and to Prof. E.V. Sharkov for his editorial works. I would also like to thank Springer-Verlag Wien for letting me use Fig. 1 b, Fig. 3b and Fig. 4c, d (with some modifications) used in my recently published article in Mineralogy and Petrology. 
11. Appendix 1. Molar volume of minerals (data from Robie, 1966)

\begin{tabular}{llcc}
\hline & formula & $\begin{array}{c}\text { gram f.w. } \\
\text { gr }\end{array}$ & $\begin{array}{c}\text { molar volume } \\
\mathrm{cm}^{3}\end{array}$ \\
\hline Enstatite & $\mathrm{MgSiO}_{3}$ & 100.41 & 31.47 \\
Spinel & $\mathrm{MgAl}_{2} \mathrm{O}_{4}$ & 142.28 & 39.72 \\
Forsterite & $\mathrm{Mg}_{2} \mathrm{SiO}_{4}$ & 140.73 & 43.67 \\
Pyrope & $\mathrm{Mg}_{3} \mathrm{Al}_{2} \mathrm{Si}_{3} \mathrm{O}_{12}$ & 403.19 & 113.3 \\
\hline
\end{tabular}

12. Appendix 2. Comparison between bulk compositions of kelyphites and their mother garnet in some crustal garnet peridotites

\begin{tabular}{|c|c|c|c|c|c|c|c|c|}
\hline & \multicolumn{2}{|c|}{ (1) } & \multicolumn{2}{|c|}{ (2) } & \multicolumn{2}{|c|}{ (3) } & \multicolumn{2}{|c|}{ (4) } \\
\hline & Grt & Kely & $\mathrm{Grt}^{* *}$ & Kely $^{* *}$ & Grt & Kely & Grt & Kely \\
\hline $\mathrm{SiO}_{2}$ & 42.8 & 41.4 & 42.1 & 37.6 & 42.4 & 39.9 & 41.5 & 41.3 \\
\hline $\mathrm{TiO}_{2}$ & 0.0 & 0.0 & 0.7 & 0.6 & 0.1 & 0.0 & 0.1 & 0.0 \\
\hline $\mathrm{Al}_{2} \mathrm{O}_{3}$ & 21.1 & 18.4 & 21.5 & 17.8 & 23.1 & 20.7 & 23.6 & 21.1 \\
\hline $\mathrm{Cr}_{2} \mathrm{O}_{3}$ & 4.0 & 2.6 & 1.7 & 1.7 & 1.3 & 1.3 & 1.0 & 1.1 \\
\hline $\mathrm{FeO}^{*}$ & 8.2 & 6.0 & 8.5 & 9.0 & 9.3 & 7.4 & 11.0 & 7.2 \\
\hline $\mathrm{MnO}$ & 0.4 & 0.2 & 0.3 & 0.2 & 0.4 & 0.1 & 0.6 & 0.2 \\
\hline $\mathrm{MgO}$ & 20.7 & 29.0 & 20.7 & 28.2 & 19.1 & 27.0 & 18.1 & 26.7 \\
\hline $\mathrm{NiO}$ & 0.0 & 0.1 & n.d. & n.d. & 0.0 & 0.0 & 0.0 & 0.0 \\
\hline $\mathrm{CaO}$ & 3.7 & 3.5 & 4.3 & 4.0 & 5.7 & 2.6 & 5.2 & 3.0 \\
\hline $\mathrm{Na}_{2} \mathrm{O}$ & 0.0 & 0.0 & n.d. & n.d. & 0.0 & 0.1 & 0.0 & 0.3 \\
\hline Total & 100.9 & 101.1 & 100.0 & 99.1 & 101.4 & 99.0 & 100.9 & 100.9 \\
\hline
\end{tabular}

Grt, garnet; Kely, kelyphite. ** obtained by wet chemical analyses; other analyses of kelyphites obtained by calculation from modal analysis and microprobe analyses of minerals.

$\mathrm{FeO}^{*}$ total $\mathrm{Fe}$ as $\mathrm{FeO}$; n.d., not determined.

(1) Ugelvik, Norway, Obata and Spengler, unpublished; (2) Sklené, Czech Bohemia, Fiala (1966); (3), (4) Ultental, Italy, Godard \& Martin (2000).

Note a significant decrease in $\mathrm{Al}_{2} \mathrm{O}_{3}$ and increase in $\mathrm{MgO}$ in the kelyphitizaion of garnet in all examples.

\section{References}

Anderson, O. L., Schreiber, E., Lieberman, R. C. \& Soga, N. (1968) Some elastic constant data on minerals relevant to geophysics, Rev. Geophys., 6, 491-524.

Becke, F. (1882) Die Gneissformation des niederösterreichische Waldviertels. Mineral. und Petrogr. Mittheilungen herausgegeben von Tschermak N. F., 4, 189-364, 322-327.

Chadwick, G.A. (1972) Metallography of Phase Transformations, Butterworth \& Co Ltd., pp. 302.

Darken, L. S. \& Fisher, R. M. (1962) Some observations on the growth of pearlite, In: Decomposition of Austenite by Diffusional Processes, Zackay, V.F. \& Aaronson, H.I. (Eds.), Interscience Publishers, John Wiley \& Sons, Inc., New York, pp. 621.

Dégi, J., Abart, R., Kalman, T., Bali, E., Wirth, R. \& Rhede, D. (2010) Symplectite formation during decompression induced garnet breakdown in lower crustal mafic granulite xenoliths: mechanisms and rates, Contrib. Mineral. Petrol. 159, 293-314. 
Fiala, J. (1966) The distribution of elements in mineral phases of some garnet peridotites from the Bohemian massif, Krystalinikum, 4, 31-53.

Godard, G. \& Martin, S. (2000) Petrogenesis of kelyphites in garnet peridotites: a case study from the Ulten zone, Italian Alps, J. Geodynamics, 30, 117-145.

Grigoriev, D. P. (1965) Ontogeny of Minerals, Israel Programme for Sci. Transl. Jerusalem.

Hillert, N. (1962) The formation of pearlite, In: Decomposition of Austenite by Diffusional processes, Zackay, V.F. \& Aaronson, H.I. (Eds.), Interscience Publishers, John Wiley \& Sons, Inc., New York, pp. 621.

Hiroi, Y., Motoyoshi, Y., Shiraishi, K. \& Mathavan, V. (1997) Local formation of hercyniteplagioclase symplectite after garnet and sillimanite in khondalite from Habarana, Sri Lanka: mineral textures, Proceedings NIPR Symposium on Antarctic Geoscience, 10, 153-164.

Joesten, R. (1991) Grain-boundary diffusion kinetics in silicate and oxide minerals. In: Diffusion, Atomic Ordering, and Mass Transport, Ganguly, J. (Ed.), Springer-Verlag, New York. pp. 567.

Kamei, A., Obata, M, Michibayashi, K., Svojtka, M. \& Hirajima, T. (2010) Two contrasting fabric patterns of olivine observed in garnet and spinel peridotite from a mantlederived ultramafic mass enclosed in felsic granulite, the Moldanubian Zone, Czech Republic, J. Petrology, 51, 101-123.

Kirkaldy, J. S. (1999) Spontaneous pattern formation in metallic and ceramic materials. In: Growth, Dissolution and Pattern Formation in Geosystems, Jamtveit, B. \& Meakin (Eds.), pp. 189-220, Kluwer Academic Publishes.

Kretz, R. (1983) Symbole for rock-forming minerals. Amer. Mineral., 68, 288-279。

Kretz, R. (1994) Metamorphic Crystallization, John Wiley \& Sons, Inc, New York, pp. 507.

Kushiro, I. \& Yoder, H. S., Jr. (1966) Anorthite-forsterite and anorthite-enstatite reactions and their bearing on the basalt eclogite transformation, J. Petrology, 7, 337-362.

MacGregor, I. D. (1974) The system $\mathrm{MgO}-\mathrm{Al}_{2} \mathrm{O}_{3}-\mathrm{SiO}_{2}$ : solubility of $\mathrm{Al}_{2} \mathrm{O}_{3}$ in enstatite for spinel and garnet peridotite compositions, Amer. Mineral., 59, 110-119.

Mercier, J. C. \& Nicolas, A. (1975) Textures and fabrics of upper mantle peridotites as illustrated by xenoliths from basalts, J. Petrology, 16, 454-487.

Mongkoltip, P. \& Ashworth, J. R. (1983) Quantitative estimation of an open system symplectite-forming reaction: restricted diffusion of $\mathrm{Al}$ and $\mathrm{Si}$ in coronas around olivine, J. Petrology, 24, 635-661.

Morishita, T. (2000) Three-dimensional microstructure of symplectite minerals in the Horoman peridotite: a preliminary analysis, J. Geological Society of Japan 106, 800-811.

Morishita, T. \& Arai, S. (2003) Evolution of spinel-pyroxene symplectite in spinel-lherzolites from the Horoman Complex, Japan, Contrib. to Mineral. Petrol. 144, 509-522.

Morishita, T., Tsuchiyama, A., Nakano, T. \& Uesugi, K. (2003) Observations of three-dimensional microstructures of symplectitic minerals in the Horoman peridotite complex using a high-resolution X-ray CT system at SPring-8, J. Geol. Soc. Japan, 109, III-IV.

Naemura, K., Hirajima, T. \& Svojtka, M. (2009) The pressure-temperature path and the origin of phlogopite in spinel-garnet peridotites from the Blansky Les Massif of the Moldanubian Zone, Czech Repblic, J. Petrology, 50, 1795-1827.

Nockolds, S. R., Knox, R. W. O'B. \& Chinner, G. A. (1978) Petrology for Students, Cambridge University Press, London, pp. 435.

Obata, M. (1994) Material transfer and local equilibria in a zoned kelyphite from a garnet pyroxenite, Ronda Spain, J. Petrology, 35, 271-287. 
Obata, M., Morishita, R. \& Tanaka, K. (1997) The microstructure of pyroxene-spinel symplectite from the Horoman peridotite and its formation processes, Memoir Geol. Soc. Japan, No. 47, 163-171 (in Japanese with English abstract).

Obata, M. (2007) Petrography revived: the science of rock texture, (in Japanese with English abstracts and figure captions), Japanese Magazine of Mineral. Petrol. Sci., 36, 168-181.

Obata, M. \& Ozawa, K. (2011) Topotaxic relationships between spinel and pyroxene in kelyphite after garnet in mantle-derived peridotites and their implications to reaction mechanism and kinetics, Mineralogy and Petrology, 101, 217-224.

Obata, M., Ozawa, K. \& Naemura, K. (2011) A kelyphite produced by an isochemical breakdown of garnet in a Czech garnet peridotite from the Moldanubian Zone, Abstract of Japan Geoscience Union Meeting (SCG067-03), Makuhari, May 2011.

Odashima, N., Morishita, T., Ozawa K., Nagahara, H., Tsuchiyama, A. \& Nagashima, R. (2008) Formation and deformation mechanisms of pyroxene-spinel symplectite in an ascending mantle, the Horoman peridotite complex, Japan: An EBSD (electron backscatter diffraction) study, Japanese J. of Mineralogical and Petrological Sciences, 103, 1-15.

Ozawa, K. (2004) Thermal history of the Horoman peridotite complex: a record of thermal perturbation in the lithospheric mantle, J. Petrology, 45, 253-273.

Ozawa, K. \& Takahashi, N. (1995) P-T history of a mantle diapir: the Horoman peridotite complex, Hokkaido, northern Japan, Contrib. Mineral. Petrol., 45, 253-273.

Putnis, A. (1992) Introduction to Mineralogical Sciences, Cambridge Univ. Press, Cambridge, pp. 457.

Robie, R. A. (1966) Thermodynamic properties of minerals, In: Handbook of Physical Constants, Sydney, P. Clark (Ed.), GSA Memoir 97.

Sajeev, K., Osanai, Y., Connolly, J. A. D., Suzuki, S., Ishioka, J., Kagami, H. \& Rino, S. (2007) Extreme crustal metamorphism during a Neoproterozoic event in Sri Lanka: A study of dry mafic granulites, J. Geology, 115, 563-582.

Shuto, K. \& Osanai, Y. (2002) Introduction to Petrology (in Japaneses), Kyoritu Shuppan, pp 272.

Smith, D. (1977) The origin and interpretation of spinel-pyroxene clusters in peridotite. J. Geology, 85, 476-482.

Spengler, D., van Roermund, H. L. M., Drury, M. R., Ottolini, L., Mason, P. R. D. \& Davies, G. R. (2006) Deep origin and hot melting of an Archaean orogenic peridotite massif in Norway, Nature, 440, 913-917.

Takahashi, N. \& Arai, S. (1989) Textural and chemical features of chromian spinel-pyroxene symplectite in the Horoman peridotite, Hokkaido, Japan, Sci. Rep. Inst. Geosci. Univ. Tsukuba Sec B, 10, 45-55.

Thompson, J. B. (1959) Local equilibrium in metasomatic processes, In: Researches in Geochemistry, Abelson, P. H. (Ed.), 427-57, John Wiley, New York.

Taylor, W. R. (1998) An experimental test of some geothermometer and barometer formulation for upper mantle peridotites with application to the thermobarometry of fertile lherzolite and garnet websterite, Neues Jahrbuch fur Mineralogie, Abhandlungen, 172, 381-408.

Vernon, R.H. (2004) A Practical Guide to Rock Microstructure, Oxford University Press, Oxford, pp. 593.

Wood, B. J. \& Banno, S. (1973) Garnet-orthopyroxne and orthopyroxene-clinopyroxene relationship in simple and complex systems, Contrib. Mineral. Petrol., 42, 109-124. 


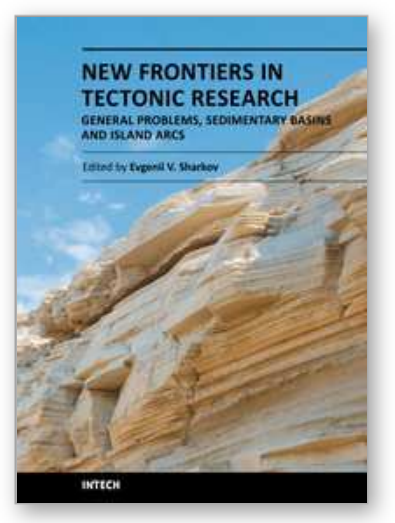

\author{
New Frontiers in Tectonic Research - General Problems, \\ Sedimentary Basins and Island Arcs \\ Edited by Prof. Evgenii Sharkov
}

ISBN 978-953-307-595-2

Hard cover, 350 pages

Publisher InTech

Published online 27, July, 2011

Published in print edition July, 2011

This book is devoted to different aspects of tectonic research. Syntheses of recent and earlier works, combined with new results and interpretations, are presented in this book for diverse tectonic settings. Most of the chapters include up-to-date material of detailed geological investigations, often combined with geophysical data, which can help understand more clearly the essence of mechanisms of different tectonic processes. Some chapters are dedicated to general problems of tectonics. Another block of chapters is devoted to sedimentary basins and special attention in this book is given to tectonic processes on active plate margins.

\title{
How to reference
}

In order to correctly reference this scholarly work, feel free to copy and paste the following:

Masaaki Obata (2011). Kelyphite and symplectite: textural and mineralogical diversities and universality, and a new dynamic view of their structural formation, New Frontiers in Tectonic Research - General Problems, Sedimentary Basins and Island Arcs, Prof. Evgenii Sharkov (Ed.), ISBN: 978-953-307-595-2, InTech, Available from: http://www.intechopen.com/books/new-frontiers-in-tectonic-research-general-problems-sedimentarybasins-and-island-arcs/kelyphite-and-symplectite-textural-and-mineralogical-diversities-and-universality-and-anew-dynamic1

\section{INTECH}

open science | open minds

\section{InTech Europe}

University Campus STeP Ri

Slavka Krautzeka 83/A

51000 Rijeka, Croatia

Phone: +385 (51) 770447

Fax: +385 (51) 686166

www.intechopen.com

\section{InTech China}

Unit 405, Office Block, Hotel Equatorial Shanghai

No.65, Yan An Road (West), Shanghai, 200040, China 中国上海市延安西路65号上海国际贵都大饭店办公楼 405 单元

Phone: +86-21-62489820

Fax: $+86-21-62489821$ 
(C) 2011 The Author(s). Licensee IntechOpen. This chapter is distributed under the terms of the Creative Commons Attribution-NonCommercialShareAlike-3.0 License, which permits use, distribution and reproduction for non-commercial purposes, provided the original is properly cited and derivative works building on this content are distributed under the same license. 